\title{
The Role of Central Bank Operating Procedures in an Economy with Productive Government Spending
}

\author{
Jordi Caballé · Jana Hromcová
}

Accepted: 10 January 2010 / Published online: 28 January 2010

(C) Springer Science+Business Media, LLC. 2010

\begin{abstract}
We reexamine some of the issues related to the choice of the monetary policy instrument in a dynamic general equilibrium model exhibiting endogenous growth in which a fraction of productive government spending is financed by means of issuing currency. We evaluate the performance of four monetary instruments: monetary aggregate targeting, nominal interest rate targeting, inflation rate targeting and real interest rate targeting. We show that a switch from any other targeting procedure towards the real interest rate targeting may be welfare improving even if the real interest rate targeting is a policy that delivers the most volatile consumption in the short run.
\end{abstract}

Keywords Monetary policy targets · Productive government spending

\section{JEL Classification E52 $\cdot$ E62}

\section{Introduction}

It is widely accepted that the central bank operating procedures could affect the fluctuations of macroeconomic variables. Monetary authorities may control directly one instrument out of several possible choices. For example, they can target the money

\footnotetext{
J. Caballé (ه)

Institute for Economic Analysis (CSIC) and Departament d'Economia i d'Historia Economica, Universitat Autonoma de Barcelona, Barcelona, Spain

e-mail: jordi.caballe@uab.es

J. Hromcová

Departament d'Economia Aplicada, Universitat Autonoma de Barcelona, Barcelona, Spain
} 
supply (or monetary aggregate), the nominal interest rate, the inflation rate or the real interest rate, while the others adjust endogenously. As the targeting of one of the instruments could lead to a superior performance than the targeting of the others, monetary authorities should decide which instrument to choose. In this paper we want to reexamine some of the issues related to the choice of the monetary policy instrument in a general equilibrium model exhibiting endogenous growth where the productive government spending is partially financed by means of currency printing. We evaluate the performance of four monetary instruments from the point of view of both fluctuations of endogenous variables and welfare.

As it was already pointed out by Poole (1970) in an IS-LM framework, the problem of finding the optimal policy instrument is irrelevant when we are dealing with a non-stochastic economy. The question becomes however relevant under uncertainty. Poole evaluated the performance of two procedures, the monetary aggregate targeting and the nominal interest rate targeting, by looking at output and price fluctuations. He found that when the origin of disturbances comes mainly from money demand shocks to target the nominal interest rate is the best policy in terms of output stabilization, whereas to target the rate of monetary growth is the most stabilizing policy when the origin of disturbances comes mainly from real shocks. Concerning price fluctuations, he recommends nominal interest rate targeting as a more price stabilizing policy.

After Poole's contribution the question of the choice between monetary aggregate targeting or nominal interest rate targeting when the economy is subject to technology, fiscal and/or monetary shocks has been analyzed by several authors through more sophisticated frameworks. For example, Carlstrom and Fuerst (1995) consider a cash-in-advance model with portfolio rigidity in the households' cash-saving choice, and find that interest rate targeting is the instrument that outperforms monetary aggregate targeting in terms of welfare even if the former delivers more volatile output. Collard et al. (1998) evaluate those two targeting procedures in a growth model with labor augmenting technological progress. They conclude that nominal interest rate targeting results in higher welfare and lower volatility of both output and inflation rate regardless of the origin of the shocks generating the disturbances. Canzoneri and Dellas (1998) study the effect of the choice between monetary aggregate and nominal interest rate targeting on the level of the risk premium in a cash-inadvance economy without capital where labor contracts induce rigidities. They find that, under nominal interest rate targeting, the average level of the real interest rate is higher and prices are less volatile. Nevertheless, they conclude that it is not clear which policy performs better in terms of welfare. Collard and Dellas (2005) analyze a related question in a model with capital, staggered prices, and money in the utility function. They find that the targeting procedure that performs better in terms of welfare differs from the one that minimizes the output fluctuations. The relative risk aversion parameter plays a crucial role in their analysis since, when the relative risk aversion is higher than unity, nominal interest rate performs better for fiscal shocks, whereas monetary aggregate targeting leads to higher welfare under liquidity shocks.

Considering a wider choice of monetary policy targets, Collard and Dellas (2006) examine the performance of the money growth rate targeting, nominal interest 
rate targeting, and inflation targeting in a model with physical capital with adjustment and transaction costs for money demand. Independently of many key features of their model (risk aversion, size of markup, level of capital adjustment costs) perfect inflation targeting delivers the highest welfare. However, they conclude that the welfare under perfect inflation stability is not significantly different from the one achieved under the other targeting procedures they analyze. With respect to the comparison between monetary aggregate and interest rate targeting, their results imply that nominal interest rate targeting delivers higher welfare, at least in a more realistic model with investment. It is also the case that the instrument that leads to higher welfare does not necessarily provide the best stabilization of output. Bhattacharya and Singh (2008) in an overlapping generation model find that when the shocks are real, welfare is higher under monetary aggregate targeting and, when the shocks are nominal and not large, inflation rate targeting leads to higher welfare. Some papers also study the performance of the nominal income targeting. Canzoneri and Dellas (1998), for example, conclude that nominal income targeting is an intermediate case between monetary aggregate and nominal interest rate targeting since it acts like monetary aggregate targeting for productivity shocks and like nominal interest rate targeting for liquidity shocks. Finally, Kim and Henderson (2005) find that the nominal income growth targeting leads to higher welfare than the inflation targeting.

As we have seen, the specific features of the previous models lead to different conclusions about the welfare achieved under alternative targeting procedures. We want to contribute to the debate by introducing a new link between the monetary and the real side of the economy and by analyzing the performance of the model under an instrument not considered in the previous literature, namely, the real interest rate targeting. On the one hand, monetary policy will have a direct real effect since we assume that productive government spending could be financed through seigniorage. On the other hand, by allowing the central bank to target the real interest rate, the monetary authority dissolves the uncertainty about what borrowers have to pay in real terms. Note that a central bank with an inflation rate objective that controls the nominal interest rate has in fact an implicit real interest rate target.

In this paper we deal with an endogenous growth model in which three kinds of shocks usually taken into account in the literature are present: productivity (or technology), fiscal (or government spending) and liquidity (or money demand) shocks. We consider a production function with productive government spending. Barro (1990) assumes in his model that the government spending is entirely financed by means of a flat rate income tax. Blackburn and Hung (1996) assume instead that the government finances its spending through seigniorage, that is, by printing money. We will assume that the government obtains revenues from taxes, from issuing debt, and from seigniorage. If the revenues from income taxes were disregarded, the model would display unrealistic values for the money growth rate and the nominal interest rates. Therefore, we combine both fiscal and monetary financing as in Palivos and Yip (1995). The financing of the government spending by seigniorage allows our model to create a new link between the monetary and the real side of the economy since the inflationary revenues obtained by the government are transformed into productive spending. Under this specification, technology and fiscal shocks 
enter directly into the production function. Finally, money demand shocks are introduced in the form of a modified cash-in-advance constraint in the spirit of Woodford (1991). ${ }^{1}$

Let us mention that many countries subject to large tax evasion have used seigniorage to obtain easy inflationary revenues (see Roubini and Sala-i-Martin 1992, 1995). Moreover, Fishlow and Friedman (1994) document empirically for the cases of Argentina, Brazil and Chile that the governments of these countries during the period 1950-1990 have relied heavily on inflationary financing in order to get the revenue that their inefficient tax systems were unable to generate. These authors argue that the inflation associated with money creation results in less reported income by taxpayers and, hence, to less regular fiscal revenues collected by the tax authority. This is due to the so called Tanzi-Olivera effect, according to which both the delay in tax auditing and the lack of indexation of tax penalties reduces the real fines to be paid by the taxpayers who are caught evading by the tax enforcement agency. Therefore, inflation provides additional incentives to tax evading activities. Note that the same amount of seigniorage revenue can be obtained by selecting one of the monetary policy instruments and letting the money supply to accommodate the demand for liquidity by the private sector. However, the stabilizing implications of different instruments could be quite different in a stochastic economy exposed to shocks. According to this view of monetary policy, we consider an economy where the public spending to GDP ratio is exogenously given and we let the regular fiscal revenue, and thus either the tax rate or the amount of public debt outstanding, to be endogenously determined in equilibrium as a function of the selected level of one of the monetary policy instruments.

We evaluate the influence of all three aforementioned shocks on the growth rate of the economy, inflation rate, consumption and welfare under four scenarios: when the monetary authority follows monetary aggregate targeting, nominal interest rate targeting, inflation rate targeting or real interest rate targeting. The new connection that we introduce between the monetary and the real side of the economy may alter the proportion of government spending that is financed through regular fiscal revenues or through seigniorage. As a reaction to a real shock, money demand has to adjust keeping the modified cash-in-advanced binding. This adjustment does not have to be the same under different targeting procedures as it may induce variations in taxes, public debt, disposable income, capital and consumption, which then imply differences in the volatilities of the other variables and in welfare.

Concerning the volatilities of the endogenous variables, we find that under real shocks the growth rate of output and consumption exhibit the smallest fluctuation under the inflation rate targeting, but the differences with the nominal interest rate targeting and the monetary aggregate targeting are negligible. The inflation rate and the growth rates of output and consumption all exhibit the highest variability for the real interest rate targeting. The real interest rate targeting implies a high stability in capital accumulation and the effect of real shocks on output is thus channeled towards consumption. High volatility of consumption in turn affects the fluctuations of output

\footnotetext{
1 Our model coincides with the one of Palivos and Yip (1995) only in the form of the government spending financing. They do not consider productive government spending, nor work with a modified cash-in-advance constraint.
} 
and prices. Under the money demand shocks these variables are the least volatile under the nominal interest rate targeting and the most volatile under monetary aggregate targeting. When the growth rate of nominal balances is fixed, the adjustment of the real money to shocks can only happen via prices and, thus, the variability in the inflation rate is the highest, which affects in turn the fluctuations of the other real variables.

Our welfare analysis implies that when the economy is subject to technology or government spending shocks and the relative risk aversion is higher than unity, the real interest rate targeting is the procedure that delivers the highest welfare, followed by the nominal interest rate targeting, monetary aggregate targeting, and inflation rate targeting. Inflation rate targeting performs the best when the relative risk aversion is low. Under money demand shocks the monetary aggregate targeting delivers the highest welfare, followed by the real interest rate targeting, nominal interest rate targeting, and inflation rate targeting. We find that a high volatility of the endogenous variables is not necessarily welfare reducing as we have to look at the frequency of the volatility, that is, we have to distinguish between short-term and long-term fluctuations. In fact, if the individuals' risk aversion is high, the inflation rate targeting, which leads to the least volatile economy in the short run, is not the best instrument in terms of welfare since the real interest rate targeting delivers a consumption path that is closer to its deterministic path and, thus, the latter procedure performs better in terms of welfare.

The remainder of the paper is organized as follows. The model is described in Sect. 2. We describe the solution technique and calibrate the model in Sect.3. The evaluation and comparison of all targeting procedures concerning impulse-responses, fluctuations, and welfare is presented in Sect. 4. Section 5 provides some final remarks.

\section{The Model}

\subsection{Households}

Let us consider an economy populated by infinitely lived identical households. The preferences of a representative household at time $t$ are given by the following utility function defined over the random stream of consumption $\left\{c_{j}\right\}_{j=t}^{\infty}$ :

$$
E_{t}\left[\sum_{j=t}^{\infty} \beta^{j-t}\left(\frac{c_{j}^{1-\theta}-1}{1-\theta}\right)\right]
$$

where $\beta \in(0,1)$ is the discount factor, $\theta>0$ is the inverse of the elasticity of intertemporal substitution (or the index of relative risk aversion). At the beginning of the economy a monetary policy is set. The sequence of events within each period is the following:

(1) Individuals enter a given period $t$ with a certain amount of monetary balances $M_{t}$, nominal bonds $B_{t}$, and real assets $z_{t}$.

(2) Individuals learn the state of the economy. The state of the economy is characterized by a vector of technology, money demand, and public spending to GDP 
ratio shocks, $\left(A_{t}, s_{t}, G_{t}\right)$. We assume that all these three shocks are mutually independent.

(3) Individuals supply inelastically a unit of labor and production takes place.

(4) Individuals receive their real income in the form of a wage $w_{t}$ and a return to asset holdings at the rate $q_{t}$.

(5) Income is taxed by the government at the rate $\tau_{t}$.

(6) The goods market opens and individuals purchase consumption using their money balances and a fraction of their after-tax income.

(7) The monetary holdings of agents are augmented by a lump sum transfer $X_{t}$ from the government. The amount $X_{t}$ is endogenously determined in the system according to the assumed operation of the monetary policy.

(8) The financial market opens and agents choose their nominal money holdings $M_{t+1}$ and their assets holdings $z_{t+1}$ for period $t+1$. They also purchase (or issue) one-period nominally denominated pure discount bonds paying $B_{t+1}$ units of money at period $t+1$ while they cost $\frac{B_{t+1}}{1+i_{t+1}}$ units of money at period $t$. The variable $i_{t+1}$ is the nominal interest rate between period $t$ and $t+1$.

The budget constraint for period $t$ is thus the following:

$c_{t}+z_{t+1}+\frac{M_{t+1}}{p_{t}}+\frac{B_{t+1}}{\left(1+i_{t+1}\right) p_{t}} \leq\left(1-\tau_{t}\right)\left[w_{t}+q_{t} z_{t}\right]+z_{t}+\frac{M_{t}}{p_{t}}+\frac{B_{t}}{p_{t}}+\frac{X_{t}}{p_{t}}$.

In strict cash-in-advance models with uncertainty and a single consumption good, consumers must purchase such a good by using only currency, and the income earned in the current period cannot be converted into money until the next financial exchange. However, following Woodford (1991), we will assume here that a fraction of the $t$ period after-tax income can be used for current period purchases. Moreover, like in Canzoneri and Dellas (1998), we allow this fraction to fluctuate randomly. Therefore, the cash-in-advance constraint becomes

$$
c_{t} \leq \frac{M_{t}}{p_{t}}+s_{t}\left(1-\tau_{t}\right)\left[w_{t}+q_{t} z_{t}\right]
$$

where $s_{t}$ is the money demand shock. Money demand shocks are assumed to be lognormally distributed and to follow an autoregressive process,

$$
\ln s_{t+1}=\left(1-\rho_{s}\right) \overline{\ln s}+\rho_{s} \ln s_{t}+\varepsilon_{s, t+1},
$$

where $\rho_{s} \in(0,1), \overline{\ln s}$ is the unconditional expected value of the logarithm of the money demand shock, and the stochastic process $\left\{\varepsilon_{s, t}\right\}$ is identically and independently distributed with $\varepsilon_{s, t} \sim N\left(0, \sigma_{s}^{2}\right)$. The shock $s_{t}$ can be viewed as a measure of the efficiency of the payment system. Depending on both the after-tax income $\left(1-\tau_{t}\right)\left[w_{t}+q_{t} z_{t}\right]$ and the realization of the shock $s_{t}$ in the current period, agents know how severe their cash-in-advance constraint is. If we set $s_{t}=0$ for all $t$, we would obtain the cash-in-advance constraint usually found in standard monetary models. 
In this case, only the currency held at the end of the previous financial exchange could be used to purchase goods. A more general cash-in-advance constraint (3) allows a fraction $s_{t}$ of the after-tax income in period $t$ to be spent immediately. Clearly, a high value of $s_{t}$ means that less income has to be converted into a non-interest bearing asset (money) in order to get a given level of consumption. Thus a higher value of $s_{t}$ corresponds to a more efficient payment system and is obviously associated with a higher velocity of money.

A representative household chooses the stochastic vector sequence $\left\{c_{t}, M_{t+1}\right.$, $\left.B_{t+1}, z_{t+1}\right\}_{t=1}^{\infty}$ in order to maximize the expected discounted sum of instantaneous utilities (1) subject to the budget constraint (2) and the cash-in-advance constraint (3).

\subsection{Firms}

In this economy there are identical firms, and each of them produces the single good of this economy according to the technology represented by the gross production function

$$
y_{t}=A_{t} k_{t}^{\alpha}\left(\psi g_{t}\right)^{1-\alpha}
$$

where $y_{t}$ is the output per worker, $A_{t}$ is a random variable that represents the technology shock, $k_{t}$ is the stock of capital per worker, $g_{t}$ is the government spending per worker, $\alpha \in(0,1)$ is the elasticity of output with respect to capital and $\psi \in(0,1]$ is the fraction of government spending that is productive. ${ }^{2}$ Our formulation follows thus that of Barro (1990), according to which the flow of government spending raises factor productivity. The rate of depreciation of private capital is $\delta$. Technology shocks are also assumed to be lognormally distributed and to follow an autoregressive process,

$$
\ln A_{t+1}=\left(1-\rho_{A}\right) \overline{\ln A}+\rho_{A} \ln A_{t}+\varepsilon_{A, t+1},
$$

where $\rho_{A} \in(0,1), \overline{\ln A}$ is the unconditional expected value of the logarithm of the technology shock, and the stochastic process $\left\{\varepsilon_{A, t}\right\}$ is identically and independently distributed with $\varepsilon_{A, t} \sim N\left(0, \sigma_{A}^{2}\right)$. We normalize the number of firms so that there is a firm per consumer. Firms do not pay any fee for the use of public services associated with the flow of government spending. Consumers lend both capital and labor to the firms. Both the rental price of capital $q_{t}$ and the real wage $w_{t}$ are set competitively so that firms end up getting zero profits in equilibrium. Therefore, the competitive wage and interest rate are equal to the marginal productivities of labor and capital, respectively,

$$
\begin{aligned}
& w_{t}=(1-\alpha) A_{t} k_{t}^{\alpha}\left(\psi g_{t}\right)^{1-\alpha} \\
& q_{t}=\alpha A_{t} k_{t}^{\alpha-1}\left(\psi g_{t}\right)^{1-\alpha}-\delta
\end{aligned}
$$

\footnotetext{
2 We assume that the unproductive government spending does not enter into the representative consumer' utility as, for example, in Mankiw (1987).
} 


\subsection{Government}

The government of this economy takes the public spending to GDP ratio as given and controls the values of the monetary policy parameters. We will consider that the government spends a fraction $G_{t}$ of GDP in each period,

$$
\frac{g_{t}}{y_{t}}=G_{t}
$$

This fraction is stochastic and we assume it to be lognormally distributed and to follow an autoregressive process,

$$
\ln G_{t+1}=\left(1-\rho_{G}\right) \overline{\ln G}+\rho_{G} \ln G_{t}+\varepsilon_{G, t+1},
$$

where $\rho_{G} \in(0,1), \overline{\ln G}$ is the unconditional expected value of the logarithm of the government spending to GDP ratio, and the stochastic process $\left\{\varepsilon_{G, t}\right\}$ is identically and independently distributed with $\varepsilon_{G, t} \sim N\left(0, \sigma_{G}^{2}\right)$.

Concerning how the monetary policy is conducted, government has at its disposal four monetary instruments: it can regulate the monetary aggregate, the nominal interest rate, the inflation rate, or the real interest rate. When one of the variables is targeted, the others adjust endogenously.

We assume that government expenditures are financed by a flat-rate income tax, by printing money (seigniorage), and by borrowing, so that the government budget constraint is

$$
g_{t}=\tau_{t}\left(y_{t}-\delta k_{t}\right)+\frac{X_{t}}{p_{t}}+\Delta_{t}
$$

where $\tau_{t}$ is the tax rate on net income, $X_{t}$ is the nominal amount of money injected into the economy in period $t$, and $\Delta_{t}$ is the real net amount borrowed from consumers by selling them bonds. In order to finance the flow of its productive spending, the government borrows the amount $g_{t}$ per worker at the beginning of period $t$. Immediately after production has taken place, the government pays some of its spending by taxing income. After consumption has taken place, money and bonds are issued to finance the rest of the government spending and to repay the debt rolled over from the previous period.

We will consider two scenarios: (a) the present value of real debt is constant over time

$$
\frac{B_{t+1}}{\left(1+i_{t+1}\right) p_{t}}=\frac{B_{t}}{p_{t}} \text { for all } t
$$

which implies that the government never incurs a real deficit, i.e., $\Delta_{t}=0$ for all $t$, and the tax rate endogenously adjusts in every period so as to fulfil the government budget constraint (11), and (b) the tax rate is set constant over time, $\tau_{t}=\tau$ for all $t$, and the present value of debt varies so as to fulfil the government budget constraint. 


\subsection{Equilibrium}

All markets in this economy must clear in equilibrium. Asset market clears when

$$
k_{t}=z_{t} \text {. }
$$

From the firm profits maximization (7) and (8) we get that the net income can be replaced in equilibrium by the net production,

$$
w_{t}+q_{t} k_{t}=A_{t} k_{t}^{\alpha}\left(\psi g_{t}\right)^{1-\alpha}-\delta k_{t} .
$$

Taking into account (14) we can write the market clearing conditions for goods, money and bonds as follows:

$$
\begin{aligned}
A_{t} k_{t}^{\alpha}\left(\psi g_{t}\right)^{1-\alpha} & =c_{t}+k_{t+1}-(1-\delta) k_{t}+g_{t}, \\
M_{t+1} & =M_{t}+X_{t}=\mu_{t+1} M_{t}, \\
\frac{B_{t+1}}{\left(1+i_{t+1}\right) p_{t}} & =\frac{B_{t}}{p_{t}}+\Delta_{t},
\end{aligned}
$$

where $\mu_{t+1}$ is the gross rate of growth of the money supply.

Let $\lambda_{t}$ and $\eta_{t}$ be the non-negative Lagrange multipliers associated with the budget constraint (2) and the cash-in-advance constraint (3), respectively. The solution of the problem faced by a consumer is characterized by the following derivatives of the corresponding Lagrangian with respect to consumption, money, government bonds and capital, respectively,

$$
\begin{aligned}
& c_{t}^{-\theta}=\lambda_{t}+\eta_{t}, \\
& \frac{\lambda_{t}}{p_{t}}=\beta E_{t}\left(\frac{\lambda_{t+1}+\eta_{t+1}}{p_{t+1}}\right), \\
& \frac{\lambda_{t}}{p_{t}}=\beta\left(1+i_{t+1}\right) E_{t}\left(\frac{\lambda_{t+1}}{p_{t+1}}\right), \\
& \lambda_{t}=\beta E_{t}\left(\lambda_{t+1}\left\{1+\left(1-\tau_{t+1}\right)\left[\alpha A_{t+1}\left(\frac{\psi g_{t+1}}{k_{t+1}}\right)^{1-\alpha}-\delta\right]\right\}\right) \\
& \quad+\beta E_{t}\left(\eta_{t+1} s_{t+1}\left(1-\tau_{t+1}\right)\left[\alpha A_{t+1}\left(\frac{\psi g_{t+1}}{k_{t+1}}\right)^{1-\alpha}-\delta\right]\right) .
\end{aligned}
$$

Moreover, the following transversality conditions must hold:

$$
\lim _{j \rightarrow \infty} E_{t}\left(\beta^{t+j} \lambda_{t+j} k_{t+j+1}\right)=0
$$

and

$$
\lim _{j \rightarrow \infty} E_{t}\left(\beta^{t+j} \lambda_{t+j} \frac{B_{t+j+1}}{p_{t+j}}\right)=0 .
$$


The Lagrange multipliers $\lambda_{t}$ and $\eta_{t}$ associated with the budget constraint and cashin-advance constraints can be interpreted as the marginal utility of wealth and the marginal utility of real balances, respectively. The first order condition on consumption (18) tells us that the existence of binding liquidity constraint drives a wedge between the marginal utility of wealth and the marginal utility of consumption, since wealth cannot be used instantaneously to buy consumption goods. The left hand side of the first order condition on nominal balances (19) can be interpreted as the loss of utility due to the acquisition of an extra unit of money. At the margin this amount must be equal to the value of the liquidity services provided by such a unit of money plus the discounted expected utility increase due to capital gains resulting from price level changes. Conditions (20) and (21) combine the costs and expected gains of investing one marginal unit of wealth into government bonds and capital, respectively.

The real interest rate $r_{t+1}$ can be obtained from the real present value of an indexed bond that can be bought at period $t$ and that pays one sure unit of real wealth at the end of period $t+1$,

$$
\frac{1}{1+r_{t+1}}=\beta E_{t}\left(\frac{\lambda_{t+1}}{\lambda_{t}}\right) .
$$

Combing Eqs. 19 and 22 we can get the relationship between the real interest rate, the nominal interest rate, and the inflation rate,

$$
1+r_{t+1}=\left(1+i_{t+1}\right) \frac{E_{t}\left(\frac{\lambda_{t+1}}{\frac{p_{t+1}}{p_{t}}}\right)}{E_{t}\left(\lambda_{t+1}\right)} .
$$

Definition Given the set of initial conditions $z_{1}, M_{1}, B_{1}$, an equilibrium is a vector of stochastic processes

$$
\left\{c_{t}, z_{t+1}, w_{t}, q_{t}, k_{t}, M_{t+1}, B_{t+1}, \mu_{t+1}, i_{t+1}, r_{t+1}, p_{t}, g_{t}, \tau_{t}, A_{t}, s_{t}, G_{t}\right\}_{t=1}^{\infty}
$$

such that

(a) the representative household maximizes the discounted expected utility (1) subject to the budget constraint (2) and the cash-in-advance constraint (3) with the money demand shocks governed by (4);

(b) firms maximize profits and thus satisfy (7) and (8) with the technology shocks governed by (6);

(c) the government budget constraint (11) holds and government spending satisfies (9) and (10);

(d) the market clearing conditions for goods, assets, money and bonds, (15), (13), (16) and (17), hold in every period;

(e.1) if the government does never incur a real deficit, then $\Delta_{t}=0$ for $t=0,1, \ldots$, or

(e.2) if the government sets a constant tax rate, then $\tau_{t}=\tau$ for $t=0,1, \ldots$, where $\tau$ is exogenously given; 
(f.1) if the government pegs the rate of monetary growth, then $\mu_{t+1}=\mu$ for $t=$ $0,1, \ldots$, where $\mu$ is exogenously given, or

(f.2) if the government pegs the nominal interest rate, then $i_{t+1}=i$ for $t=0,1, \ldots$, where $i$ is exogenously given, or

(f.3) if the government pegs the inflation rate, then $\frac{p_{t+1}}{p_{t}}=f$ for $t=0,1, \ldots$, where $f$ is exogenously given, or

(f.4) if the government pegs the real interest rate, then $r_{t+1}=r$ for $t=0,1, \ldots$, where $r$ is exogenously given.

\section{Solution Method and Calibration of the Model}

\subsection{Transformation of the Model}

In order to analyze the equilibrium of the economy we have to solve simultaneously the equilibrium equations we have stated above. Since we are dealing with an endogenous growth model, many variables are non-stationary. Therefore, we will work instead with variables expressed in ratios. We define $\hat{c}_{t}$ as the consumption to current period capital ratio and $\gamma_{t+1}$ as the gross rate of growth of capital per worker,

$$
\hat{c}_{t}=\frac{c_{t}}{k_{t}} \text { and } \gamma_{t+1}=\frac{k_{t+1}}{k_{t}} \text {. }
$$

We redefine accordingly the other variables as

$$
\begin{aligned}
\hat{y}_{t} & =\frac{y_{t}}{k_{t}}, \hat{g}_{t}=\frac{g_{t}}{k_{t}}, \hat{m}_{t}=\frac{M_{t}}{p_{t} k_{t}}, \hat{b}_{t}=\frac{B_{t}}{p_{t} k_{t}}, \\
f_{t+1} & =\frac{p_{t+1}}{p_{t}}, \hat{\lambda}_{t}=\lambda_{t} k_{t}^{\theta}, \text { and } \hat{\eta}_{t}=\eta_{t} k_{t}^{\theta},
\end{aligned}
$$

where $\hat{y}_{t}, \hat{g}_{t}, \hat{m}_{t}, \hat{b}_{t}, f_{t+1}, \hat{\lambda}_{t}$ and $\hat{\eta}_{t}$ are the output to capital ratio, government spending to capital ratio, real balances to capital ratio, real bonds to capital ratio, inflation rate, stationary marginal utility of wealth, and stationary marginal utility of real balances, respectively. The equilibrium conditions written in terms of the transformed variables can be found in the Appendix.

\subsection{Solution Method}

Since the previous model does not admit a closed form solution we apply the solution technique described in detail in Uhlig (1999), which is based on the log-linearization around the steady state of the equations characterizing the equilibrium given in the Appendix. 


\subsection{Parameter Values}

We assign to the parameters of the model the values that match the quarterly US data for the period 1979:1-1997:2. However, we should point out that our objective is to perform a numerical analysis aimed at illustrating the behavior of the model and to be able to obtain helpful insights about the performance of the different monetary policy targetings.

We use variables with a bar to denote the non-stochastic steady state values of the corresponding transformed variables. The stationary value of the per worker gross growth rate is set to $\bar{\gamma}=1.00375$ as found in the data. The discount factor is set to $\beta=0.99$. We will use relative risk aversion values $\theta$ ranging from 0.5 to 4 but the baseline case will correspond to $\theta=1 .^{3}$ The value we choose for the baseline growth rate of money supply is $\bar{\mu}=1.015$, which coincides with the empirical growth rate of M1. The nominal interest rate that corresponds to this growth rate of money supply is $\bar{i}=0.025$ and the real interest rate is $\bar{r}=0.014$. The share of capital in the production function is set equal to $\alpha=0.36$. We set the value of the depreciation rate $\delta=0.0085$ in order to match the empirical averages of the ratios of consumption to output and investment to output (see Table 1). When the present value of debt is constant and the tax rate $\tau_{t}$ adjusts endogenously, seigniorage represents $1.3 \%$ of government spending, and the average level of the income tax rate is $\bar{\tau}=0.2235$. If the present value of debt is variable, the average debt to GDP ratio is $42 \%$, seigniorage also amounts to the $1.3 \%$ of government spending on average, and the level of the income tax rate is $\tau=0.2281$. To calibrate the stochastic process for technology shocks, we calculate the Solow residuals using an analogous procedure to that described in Cooley (1997). The average level $\overline{\ln A}$ of the $\log$ of the technology parameter is endogenous, and we set $\rho_{A}=0.99$, and $\sigma_{A}=0.009 .{ }^{4}$ Similarly we find that $\overline{\ln G}=-1.609$ the correlation coefficient is $\rho_{G}=0.99$, and the standard error of the shocks is $\sigma_{G}=0.011$. The parameter values for the efficiency of the payment system are determined in a similar way. We use data of consumption as a fraction of GDP and money velocity in order to generate series for $s_{t}$ using the cash-in-advance constraint. We set $\overline{\ln s}=-0.4155, \rho_{s}=0.95$ and $\sigma_{s}=0.007$. Finally, according with Pérez Sánchez (2004), the fraction of government spending that is productive is set to $\psi=0.8 .^{5}$

\footnotetext{
${ }^{3}$ Lucas (2003) argues that the values of the relative risk aversion are below 2.5 and this leads many authors to use a value close to unity.

4 Notice that in our calibration a variation in $\theta$ does not change the growth rate of the economy but it affects the average level of the technology. In order to keep a given growth rate when the consumers are more patient as $\theta$ increases, the value of the technology parameter $\overline{\ln A}$ must increase.

5 The model is calibrated in a way that the stationary non-stochastic growth rate is kept constant. For example, a change in the value of the relative risk aversion would imply a change in the growth rate if the technology parameter $A_{t}$ were not adjusted. Similarly, assigning a different value for the fraction $\psi$ of productive government spending implies changes in the average level of technology and does not affect the relative performance of the economy under different targeting procedures.
} 
Table 1 Comparison between the average empirical and calibrated values of some variables

\begin{tabular}{lll}
\hline & Data & Model \\
\hline Government spending/output & 0.2 & 0.2 \\
Consumption/output & 0.65 & 0.63 \\
Investment/output & 0.15 & 0.17 \\
Debt held by public/output & 0.42 & 0.42 \\
\hline
\end{tabular}

\section{Effects of the Four Targeting Procedures on the Stochastic Equilibrium}

\subsection{Impulse-Responses}

To see the effects of random shocks we will consider a reaction of the economy to each shock separately. Moreover, we consider the two aforementioned alternative fiscal policy scenarios: (a) the tax rate $\tau_{t}$ adjusts endogenously and the present value of outstanding debt is kept constant, and (b) the tax rate $\tau_{t}$ is kept constant and the government incurs endogenous fiscal deficits. We will assume that the economy is in the non-stochastic steady state at time $t=0$. At time $t=1$ the perturbation $\varepsilon_{A, t}\left(\varepsilon_{s, t}\right.$ or $\varepsilon_{G, t}$ ) is selected in such a way that the technology shock (the money demand shock or the government spending shock) experiences a $1 \%$ deviation from its steady state. These perturbations become $\varepsilon_{A, t}=0\left(\varepsilon_{s, t}=0\right.$ or $\left.\varepsilon_{G, t}=0\right)$ for all $t>1$. We will compare the reaction of the economy under four different targeting procedures, monetary aggregate targeting (M-targeting), nominal interest rate targeting (i-targeting), inflation rate targeting (f-targeting) and real interest rate targeting (r-targeting). For the M-targeting the monetary policy consists of pegging a constant monetary growth rate, $\mu_{t+1}=\mu$ for all $t$, for the i-targeting $i_{t+1}=i$ for all $t$, for the f-targeting $f_{t+1}=f$ for all $t$, and for the r-targeting $r_{t+1}=r$ for all $t$.

In Figs. 1, 2 and 3 we show the impulse-responses to a technology, money demand and government spending shock, respectively under the two fiscal policy scenarios mentioned above. We see that the impulse-responses are qualitatively very similar under the two assumptions concerning fiscal policy. When the tax rate adjusts endogenously, the distortion in the capital versus consumption decision is stochastic, as can be seen from the consumers' budget constraint (2). However, the variation of this distortion on the capital accumulation process is small relative to the standard crowding out effect governing the transfer of resources from the private to the public sector under a constant tax rate. All results correspond to the logarithmic utility $(\theta=1)$ and the baseline level of seigniorage, that is, when $1.3 \%$ of government spending is financed by issuing money.

Even if we next discuss the effects of each shock separately, the general picture that emerges can be summarized as follows. M-targeting, i-targeting and f-targeting exhibit almost identical impulse-responses to the three types of shocks. However, under r-targeting, impulse-responses are different when either technology or government shocks are present. In this case, as the real return from capital is kept constant, those shocks increase output and are translated mainly into more consumption. However, since monetary shocks have little real effects, r-targeting displays impulse-responses 

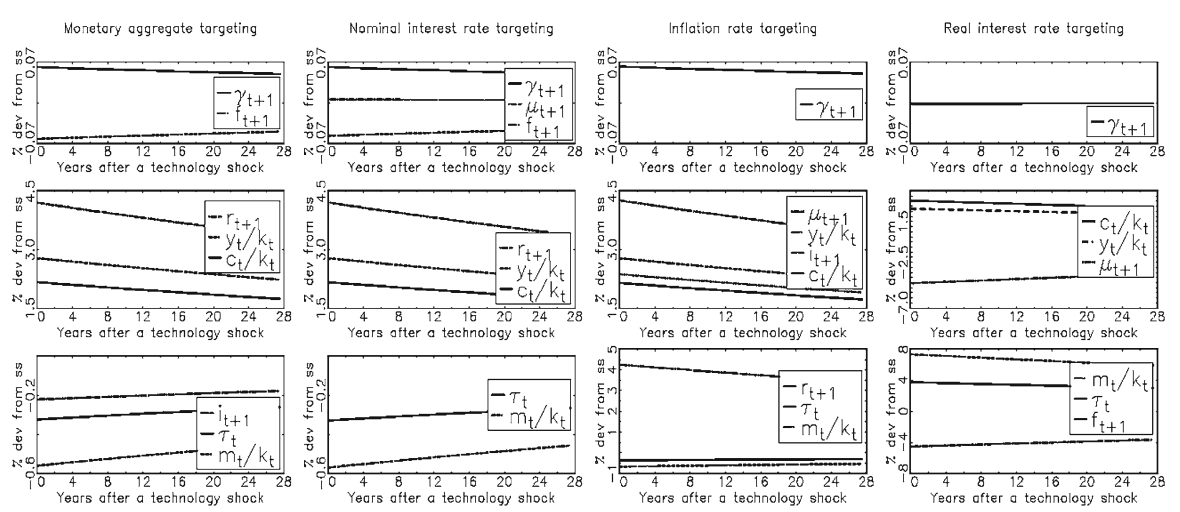

(a)

Monetory oggregate torgeting

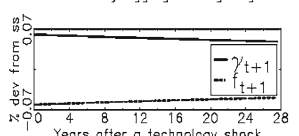

Nominal interest rote torgeting

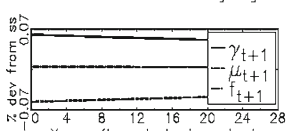

Inflation rote torgeting
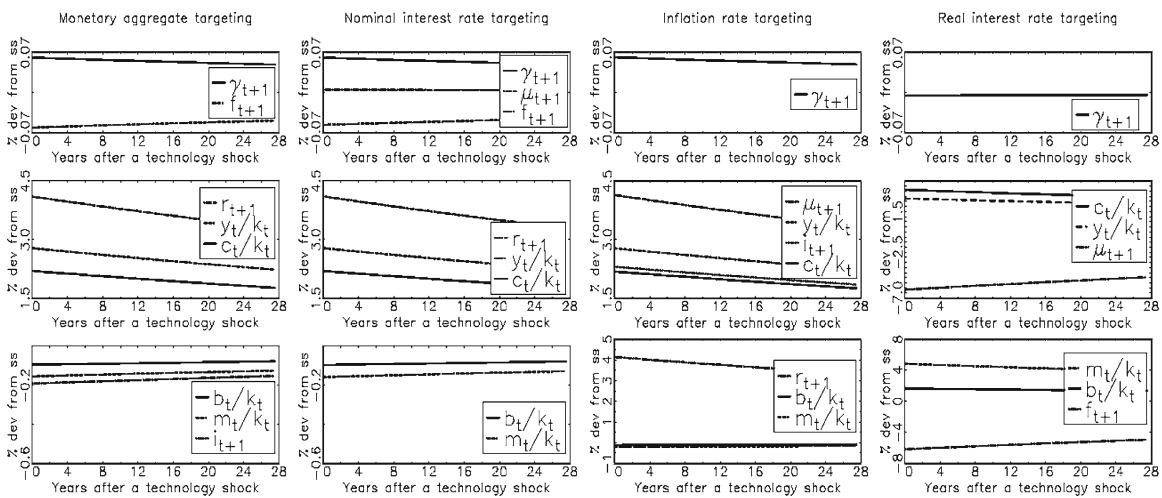

(b)

Fig. 1 Impulse responses of several variables (growth rate of capital $\gamma_{t+1}$ inflation rate $f_{t+1}$, consumption to capital ratio $c_{t}$, output to capita ratio $y_{t}$, real balances to capital ratio $m_{t}$, real interest rate $r_{t+1}$, tax rate $r_{t}$, nominal interest rate $i_{t+1}$, money growth rate $\mu_{t+1}$ ) to a shock in technology, under M-targeting (first column), under i-targeting (second column), under f-targeting (third column) and under r-targeting (fourth column) for $\theta=1$ and $\bar{\mu}=1.015$. (a) Case with stochastic tax rate and no fiscal deficit; (b) Case with constant tax rate and stochastic fiscal deficit

similar to those of the other targeting procedures when the economy is hit by those monetary shocks.

\subsubsection{Effect of Technology Shocks}

A positive transitory technology shock increases output directly. This results in a higher return on capital and higher disposable income. Thus, both consumption purchases and capital accumulation increase and the fraction of disposable income available for current purchases increases too (see Eqs. 3 and 14). In our simulations the reaction of the economy is very similar under the M-targeting, i-targeting and f-targeting. 

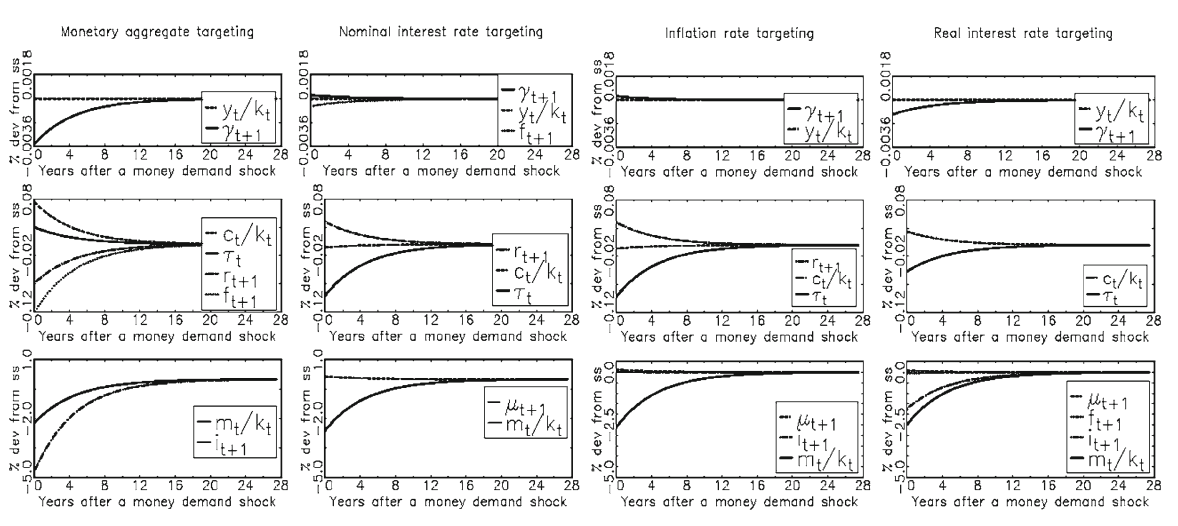

(a)
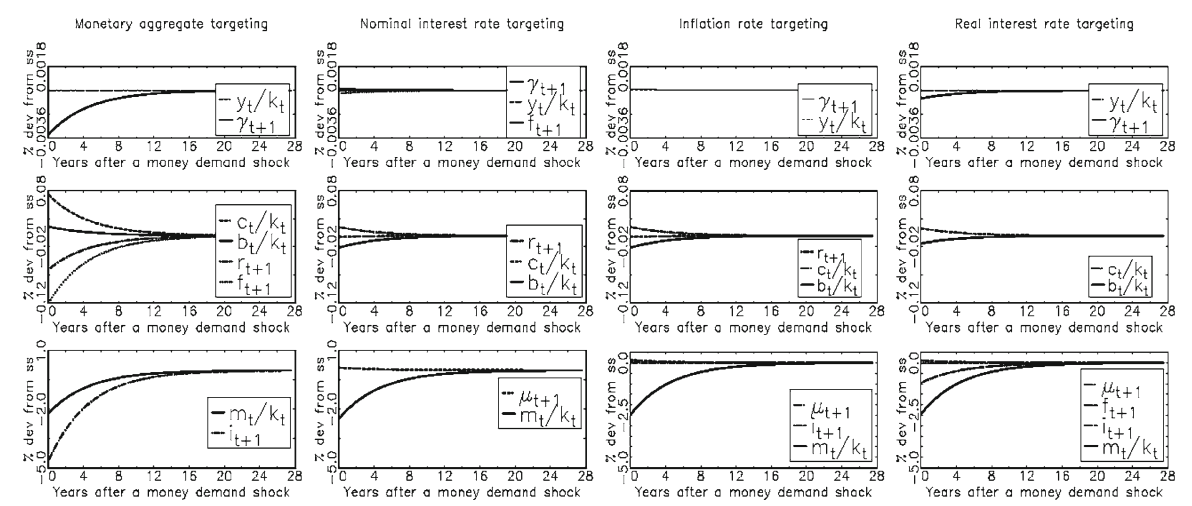

(b)

Fig. 2 Impulse responses of several variables (growth rate of capital $\gamma_{t+1}$ inflation rate $f_{t+1}$, consumption to capital ratio $c_{t}$, output to capita ratio $y_{t}$, real balances to capital ratio $m_{t}$, real interest rate $r_{t+1}$, tax rate $r_{t}$, nominal interest rate $i_{t+1}$, money growth rate $\left.\mu_{t+1}\right)$ to a shock in money demand, under M-targeting (first column), under i-targeting (second column), under f-targeting (third column) and under r-targeting (fourth column) for $\theta=1$ and $\bar{\mu}=1.015$. (a) Case with stochastic tax rate and no fiscal deficit; (b) Case with constant tax rate and stochastic fiscal deficit

The demand for real balances adjusts so that the cash-in-advance constraint is binding. ${ }^{6}$ In this particular case, at the moment of a shock, real balances decrease, which implies that future real balances will be relatively higher, and thus the growth rate of real balances experiences an increase. The adjustment process depends on the particular targeting procedure under consideration. For M-targeting, higher growth rate of

\footnotetext{
${ }^{6}$ We choose to use the timing of events due to Svensson (1985) because it simplifies the equilibrium equations. Due to this timing of events in our model, the cash-in-advance constraint (3) could become non-binding for some realizations of the shocks. Several studies that take into account analogous timing conclude that the cash-in-advance constraint is binding for almost all shock realizations, see for example Hodrick (1991) or Hromcová (2007). However, we check in our simulations that the marginal utility of real balances (the Lagrange multiplier on the cash-in-advance constraint) is always positive and we can thus write the cash-in-advance constraint with equality.
} 

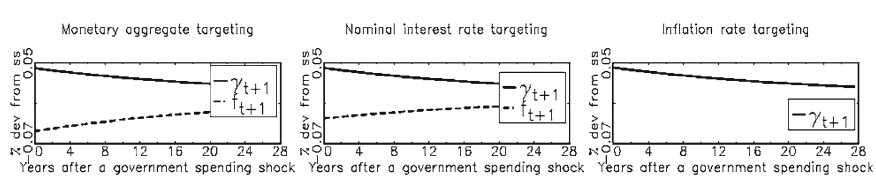

Real interest rote torgeting
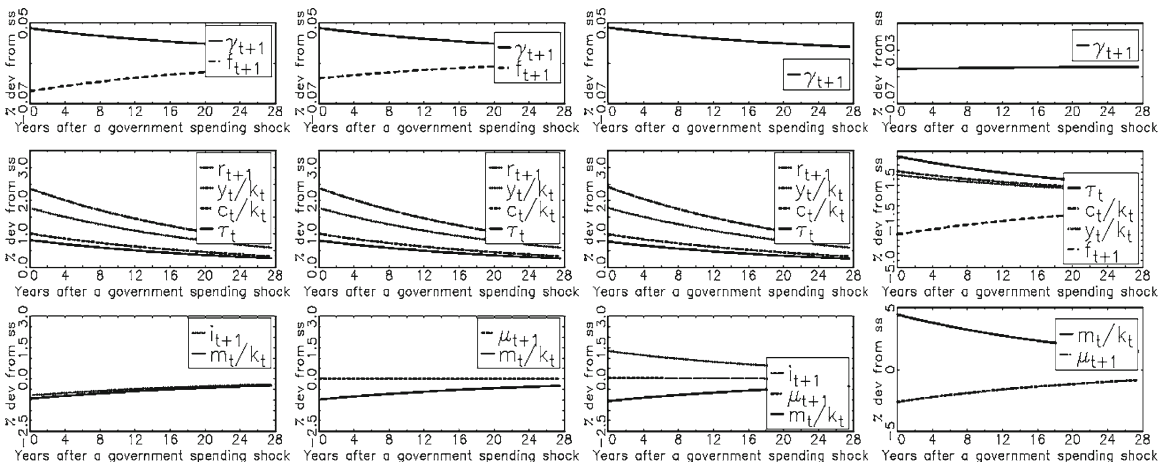

(a)

Monetory oggregate torgeting

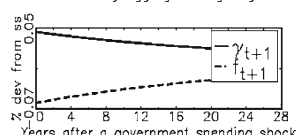

Nominal interest rate torgeting

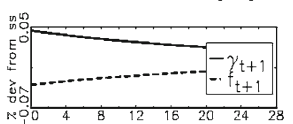

Years ofter a government spending shock

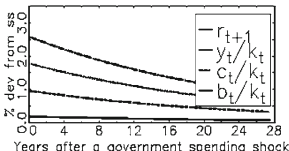

Years ofter a government spending shock

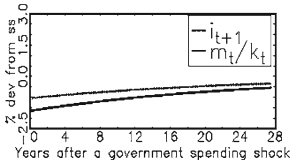

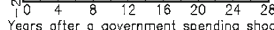
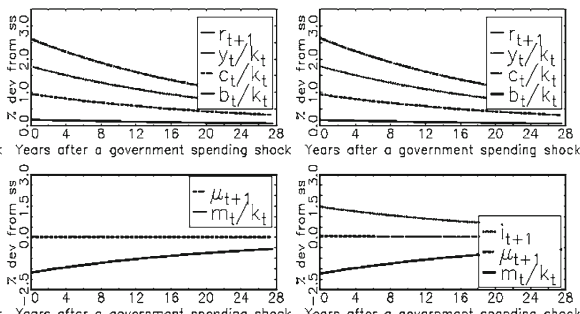

Inflation rate targeting
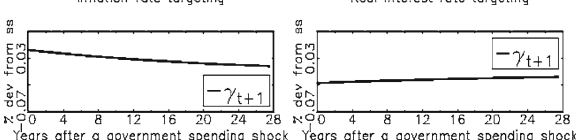

(b)

Fig. 3 Impulse responses of several variables (growth rate of capital $\gamma_{t+1}$ inflation rate $f_{t+1}$, consumption to capital ratio $c_{t}$, output to capita ratio $y_{t}$, real balances to capital ratio $m_{t}$, real interest rate $r_{t+1}$, tax rate $r_{t}$, nominal interest rate $i_{t+1}$, money growth rate $\mu_{t+1}$ ) to a shock in government spending, under M-targeting (first column), under i-targeting (second column), under f-targeting (third column) and under r-targeting (fourth column) for $\theta=1$ and $\bar{\mu}=1.015$. (a) Case with stochastic tax rate and no fiscal deficit; (b) Case with constant tax rate and stochastic fiscal deficit

real balances is achieved by adjusting prices so that the inflation rate must decrease. For the i-targeting, inflation must decrease because the real interest rate is higher and the nominal interest rate is fixed. There is also an adjustment that comes via nominal balances as the growth rate of the money supply increases slightly in the short run. For the f-targeting all the adjustment goes via nominal balances and, hence, the growth rate of nominal balances must increase.

Impulse responses are a little bit different under the r-targeting. The fact that the real interest rate is fixed prevents capital accumulation from exhibiting a significant reaction to a shock. The positive effect of the shock on the disposable income is absorbed mainly by an increase in consumption. This implies that real balances increase, which means in turn that future real balances will be relatively lower and, thus, the short-run growth rate of real balances will decrease. This behavior is obtained on the one hand by 
a decrease in the growth rate of nominal balances and on the other hand by a decrease in the inflation rate. Impulse-responses of several variables to technology shocks for the baseline parameters are plotted in Fig. $1 .^{7}$

\subsubsection{Effect of Money Demand Shocks}

A positive transitory money demand shock relaxes the liquidity constraint and, therefore, the value of money will be lower. Under the M-targeting the growth rate of the money supply cannot vary and a decrease in seigniorage (caused by a decrease in real balances) must be compensated by an increase in the revenues raised by the fiscal policy. The induced decrease in the return to capital triggers an increase in consumption. To accomplish a reduction in the real monetary balances, the current price must increase. However, as the future price will be lower than the current one, the inflation rate decreases in the short run. Notice that the effect of a $1 \%$ deviation of the efficiency of the payment system from its steady state value causes only a $0.0036 \%$ deviation of the growth rate of capital from its steady state value. In contrast, a $1 \%$ deviation of the technology shock from its steady state value triggers a deviation of the growth rate of capital of $0.07 \%$, which is roughly 20 times higher. This means that the effect of money demand shocks on real variables is almost negligible. As far as the reaction of the inflation rate is concerned, the effect of a money demand shock is double than the one of a technology shock of the same magnitude.

For the i-targeting and f-targeting, the adjustment of real balances is achieved mainly through as increase in the nominal balances, which makes the inflation rate stable in both cases. An increase in seigniorage results in a reduction of the tax rate, an increase in the disposable income, and an increase in the growth rate of capital. The small reduction of consumption comes together with this increase in the growth rate of capital. Notice however, that the deviation of the growth rate of capital is about 10 times lower than in the case of the M-targeting. Under the r-targeting the adjustment of real balances takes place via nominal balances and prices. The reaction of the growth rate of capital is constrained by the fixed real interest rate as any increase in the growth rate of nominal balances must be compensated by a decrease in prices. The growth rate of capital slightly decreases, which implies a slight increase in consumption. As before, the deviation of the growth rate of capital from its steady state value is negligible. Impulse-responses of several variables to money demand shocks for the baseline parameters are plotted in Fig. 2.

\subsubsection{Effect of Government Spending Shocks}

A positive transitory shock in government spending has a similar effect as the one of a technology shock because it affects directly the output (see Eqs. 5 and 9). The main difference is that the revenues from fiscal policy (either from taxes or debt) must temporarily increase as there is more government consumption to be paid for.

\footnotetext{
7 To keep the real interest rate fixed, inflation and nominal interest rates must react in the same direction. The magnitude of the response of the nominal interest rate is huge compared to the other variables. It experiences a decrease of $200 \%$ and, therefore, it is not included in Fig. 1.
} 
An increase in the fiscal revenues partially offsets the positive effect of the shock on income. However, disposable income still increases and the effect of a government spending shock on other variables is qualitatively analogous to the case of a positive technology shock described above. Impulse-responses of several variables to government spending shocks for the baseline parameters are plotted in Fig. 3.

\subsection{Comparison of the Four Targeting Procedures}

In this section we compare the performance of the four targeting procedures from the point of view of the volatilities of the relevant endogenous variables and of welfare. We consider again the two fiscal scenarios discussed above: one with no real deficits and endogenous tax rates and another with a constant tax rate and endogenous government deficits. The results concerning fluctuations and welfare are almost identical in both fiscal scenarios as the variation in the distortionary effects of flat-rate income taxation is almost negligible relative to the distortion arising under a constant tax rate.

\subsubsection{Fluctuations}

The three kinds of shocks introduced in our economy affect the behavior of all variables through different channels under the four targeting procedures. We will analyze the induced volatilities on consumption, on the output growth rate, and on the inflation rate. Moreover, we will evaluate the contribution of all shocks to the total volatility of these variables. Reported volatilities are calculated as the standard error of the logarithm of the Hodrick-Prescott filtered series. Simulated series have the length of 80 quarters and we evaluate averages over 1000 shock realizations. We report the volatilities for four different values of the relative risk aversion parameter, $\theta=0.5,1,2$ and 4 , and for low and high seigniorage, $\bar{\mu}=1.015$ and 4 , respectively. ${ }^{8}$ We evaluate the following cases: when the origin of disturbances are all three shocks, only technology shocks, only money demand shocks, and only government spending shocks, respectively. The results are reported in Tables 2, 3 and 4.

The volatility of consumption is almost identical for all four procedures when only monetary shocks affect the economy. It is also practically identical under M-targeting, i-targeting and f-targeting under technology and government spending shocks. Consumption is considerably more volatile for the r-targeting for technology and government spending shocks. As we already argued when analyzing the impulse-reponses, this occurs because the return to capital is stabilized by the monetary policy and, thus, consumption must absorb the effect of shocks on output.

Output and its growth rate is affected in a very similar way by all analyzed targeting procedures. The volatility is slightly higher for the real interest rate targeting due to higher variability of consumption.

\footnotetext{
8 When the average rate of growth of money supply is $1.5 \%$, about $1.5 \%$ of the government spending is financed by issuing money, i.e., seignorage is low. When the average gross growth rate of money supply is $300 \%$, from $45 \%$ up to $68 \%$ of government spending is financed by seignorage, i.e., seignorage is high. For a given value of $\bar{\mu}$, the higher is the value of risk aversion $\theta$, the higher is the percentage of government spending that must be financed by seigniorage in order to obtain the same growth rate.
} 
Table 2 Consumption volatility for the four targeting procedures; $\theta=$ relative risk aversion, $\bar{\mu}=$ average growth rate of money supply, $(A, s, G)=$ all three shocks are present, $(A)=$ only technology shocks are present, $(s)=$ only money demand shocks are present, $(G)=$ only government spending shocks are present

\begin{tabular}{|c|c|c|c|c|c|c|c|c|c|c|c|c|c|c|c|c|c|}
\hline \multirow{4}{*}{$\frac{\theta}{0.5}$} & \multirow{4}{*}{$\frac{\bar{\mu}}{1.015}$} & \multicolumn{16}{|c|}{ Consumption volatility. Case with stochastic tax rate and no fiscal deficit } \\
\hline & & \multicolumn{4}{|c|}{$(A, s, G)$} & \multicolumn{4}{|c|}{$(A)$} & \multicolumn{4}{|c|}{$(s)$} & \multicolumn{4}{|c|}{$(G)$} \\
\hline & & $\mathrm{f}$ & $\mathrm{i}$ & $\mathrm{M}$ & $\mathrm{r}$ & f & $\mathrm{i}$ & $\mathrm{M}$ & $\mathrm{r}$ & i & & $r$ & & $\mathrm{f}$ & $\mathrm{i}$ & $\mathrm{M}$ & $\mathrm{r}$ \\
\hline & & 0.01 & 0.011 & 0.012 & 0.055 & 0.01 & 0.01 & 0.01 & 0.044 & $7 \mathrm{e}-5$ & $8 \mathrm{e}-5$ & $4 \mathrm{e}-4$ & $1 \mathrm{e}-3$ & 0.004 & 0.004 & 0.005 & 0.033 \\
\hline \multirow{2}{*}{0.5} & \multirow{2}{*}{4} & $\mathrm{M}$ & $\mathrm{i}$ & $\mathrm{f}$ & $\mathrm{r}$ & $\mathrm{M}$ & $\mathrm{i}$ & $\mathrm{f}$ & $\mathrm{r}$ & $\mathrm{i}$ & $\mathrm{f}$ & $\mathrm{M}$ & $\mathrm{r}$ & $\mathrm{M}$ & $\mathrm{i}$ & $\mathrm{f}$ & $\mathrm{r}$ \\
\hline & & 0.016 & 0.018 & 0.018 & 0.16 & 0.014 & 0.015 & 0.015 & 0.075 & $4 \mathrm{e}-5$ & $4 \mathrm{e}-5$ & $2 \mathrm{e}-3$ & $2 \mathrm{e}-3$ & 0.008 & 0.01 & 0.01 & 0.13 \\
\hline \multirow{2}{*}{1} & \multirow{2}{*}{1.015} & $\mathrm{f}$ & $\mathrm{i}$ & $\mathrm{M}$ & $r$ & $\mathrm{f}$ & $\mathrm{i}$ & $\mathrm{M}$ & $\mathrm{r}$ & $\mathrm{i}$ & $\mathrm{f}$ & $\mathrm{r}$ & $\mathrm{M}$ & $\mathrm{f}$ & $\mathrm{i}$ & $\mathrm{M}$ & $\mathrm{r}$ \\
\hline & & 0.026 & 0.026 & 0.026 & 0.047 & 0.023 & 0.023 & 0.023 & 0.040 & $4 \mathrm{e}-5$ & $4 \mathrm{e}-5$ & $2 \mathrm{e}-4$ & $6 \mathrm{e}-4$ & 0.012 & 0.012 & 0.012 & 0.026 \\
\hline \multirow{2}{*}{1} & \multirow{2}{*}{4} & $\mathrm{f}$ & $\mathrm{i}$ & $\mathrm{M}$ & $\mathrm{r}$ & $\mathrm{f}$ & $\mathrm{i}$ & $\mathrm{M}$ & $\mathrm{r}$ & $\mathrm{i}$ & $\mathrm{f}$ & $\mathrm{r}$ & $\mathrm{M}$ & $f$ & $\mathrm{i}$ & $\mathrm{M}$ & $\mathrm{r}$ \\
\hline & & 0.006 & 0.007 & 0.007 & 0.074 & 0.006 & 0.007 & 0.007 & 0.057 & $2 \mathrm{e}-5$ & $2 \mathrm{e}-5$ & $2 \mathrm{e}-4$ & $1 \mathrm{e}-3$ & 0.001 & 0.002 & 0.002 & 0.047 \\
\hline \multirow{2}{*}{2} & \multirow{2}{*}{1.015} & $\mathrm{f}$ & $\mathrm{i}$ & $\mathrm{M}$ & $\mathrm{r}$ & $\mathrm{f}$ & $\mathrm{M}$ & $\mathrm{i}$ & $\mathrm{r}$ & $\mathrm{i}$ & $\mathrm{f}$ & $\mathrm{r}$ & $\mathrm{M}$ & $f$ & $\mathrm{M}$ & $\mathrm{i}$ & $\mathrm{r}$ \\
\hline & & 0.033 & 0.033 & 0.033 & 0.043 & 0.029 & 0.029 & 0.029 & 0.037 & $2 \mathrm{e}-5$ & $3 e-5$ & $8 e-5$ & $2 \mathrm{e}-4$ & 0.016 & 0.016 & 0.016 & 0.022 \\
\hline \multirow{2}{*}{2} & \multirow{2}{*}{4} & $\mathrm{f}$ & $\mathrm{M}$ & $\mathrm{i}$ & $r$ & $\mathrm{f}$ & $\mathrm{M}$ & $\mathrm{i}$ & $\mathrm{r}$ & $\mathrm{i}$ & $\mathrm{f}$ & $r$ & $\mathrm{M}$ & $\mathrm{f}$ & $\mathrm{i}$ & $\mathrm{M}$ & $\mathrm{r}$ \\
\hline & & 0.023 & 0.023 & 0.023 & 0.057 & 0.021 & 0.021 & 0.021 & 0.048 & $1 \mathrm{e}-5$ & $2 \mathrm{e}-5$ & $7 \mathrm{e}-5$ & $6 \mathrm{e}-4$ & 0.009 & 0.01 & 0.01 & 0.029 \\
\hline \multirow{2}{*}{4} & \multirow{2}{*}{1.015} & $\mathrm{f}$ & $\mathrm{M}$ & $\mathrm{i}$ & $\mathrm{r}$ & $\mathrm{f}$ & $\mathrm{M}$ & $\mathrm{i}$ & $\mathrm{r}$ & $\mathrm{i}$ & $\mathrm{f}$ & $\mathrm{r}$ & $\mathrm{M}$ & $\mathrm{f}$ & $\mathrm{M}$ & $\mathrm{i}$ & $\mathrm{r}$ \\
\hline & & 0.036 & 0.036 & 0.036 & 0.040 & 0.031 & 0.031 & 0.031 & 0.035 & $1 \mathrm{e}-5$ & $2 \mathrm{e}-5$ & $4 \mathrm{e}-5$ & $1 \mathrm{e}-4$ & 0.017 & 0.017 & 0.017 & 0.02 \\
\hline \multirow{2}{*}{4} & \multirow{2}{*}{4} & $\mathrm{f}$ & $\mathrm{M}$ & $\mathrm{i}$ & $\mathrm{r}$ & $\mathrm{f}$ & $\mathrm{M}$ & $\mathrm{i}$ & $\mathrm{r}$ & $\mathrm{i}$ & $\mathrm{f}$ & $\mathrm{r}$ & M & $\mathrm{f}$ & $\mathrm{M}$ & $\mathrm{i}$ & $\mathrm{r}$ \\
\hline & & 0.032 & 0.033 & 0.033 & 0.049 & 0.029 & 0.029 & 0.03 & 0.043 & $1 \mathrm{e}-5$ & $1 \mathrm{e}-5$ & $3 e-5$ & $3 e-4$ & 0.014 & 0.014 & 0.014 & 0.023 \\
\hline
\end{tabular}

\begin{tabular}{|c|c|c|c|c|c|c|c|c|c|c|c|c|c|c|c|c|c|}
\hline \multirow[b]{2}{*}{$\theta$} & \multirow[b]{2}{*}{$\bar{\mu}$} & \multicolumn{16}{|c|}{ Consumption volatility. Case with constant tax rate and stochastic fiscal deficit } \\
\hline & & \multicolumn{4}{|c|}{$(A, s, G)$} & \multicolumn{4}{|c|}{$(A)$} & \multicolumn{4}{|c|}{$(s)$} & \multicolumn{4}{|c|}{$(G)$} \\
\hline \multirow{2}{*}{0.5} & \multirow{2}{*}{1.015} & f & i & $\mathrm{M}$ & $\mathrm{r}$ & f & $\mathrm{i}$ & M & $\mathrm{r}$ & $\mathrm{i}$ & $\mathrm{f}$ & $\mathrm{r}$ & M & f & $\mathrm{i}$ & $\mathrm{M}$ & $\mathrm{r}$ \\
\hline & & 0.011 & 0.011 & 0.012 & 0.06 & 0.012 & 0.012 & 0.012 & 0.045 & $3 e-5$ & $3 e-5$ & $2 \mathrm{e}-5$ & $1 \mathrm{e}-3$ & 0.004 & 0.004 & 0.005 & 0.04 \\
\hline \multirow{2}{*}{0.5} & \multirow{2}{*}{4} & $\mathrm{M}$ & $\mathrm{i}$ & $\mathrm{f}$ & $\mathrm{r}$ & $\bar{M}$ & $\overline{\mathrm{i}}$ & $\mathrm{f}$ & $\mathrm{r}$ & $\mathrm{i}$ & $\mathrm{f}$ & $\mathrm{M}$ & $\mathrm{r}$ & $\mathrm{M}$ & $\mathrm{i}$ & $\mathrm{f}$ & $r$ \\
\hline & & 0.06 & 0.07 & 0.07 & 0.11 & 0.06 & 0.06 & 0.06 & 0.07 & $2 \mathrm{e}-3$ & $2 \mathrm{e}-3$ & $3 e-3$ & $8 \mathrm{e}-3$ & 0.02 & 0.03 & 0.03 & 0.075 \\
\hline \multirow{2}{*}{1} & \multirow{2}{*}{1.015} & $\mathrm{f}$ & $\mathrm{i}$ & $\mathrm{M}$ & $\mathrm{r}$ & $\mathrm{f}$ & $\mathrm{i}$ & $\mathrm{M}$ & $\mathrm{r}$ & $\mathrm{i}$ & $\mathrm{f}$ & $\mathrm{r}$ & & $\mathrm{f}$ & $\mathrm{i}$ & $\mathrm{M}$ & $\mathrm{r}$ \\
\hline & & 0.027 & 0.027 & 0.027 & 0.049 & 0.024 & 0.024 & 0.024 & 0.04 & $2 e-5$ & $2 \mathrm{e}-5$ & $1 \mathrm{e}-4$ & $5 e-4$ & 0.012 & 0.012 & 0.012 & 0.026 \\
\hline \multirow{2}{*}{1} & \multirow{2}{*}{4} & $\mathrm{M}$ & $\mathrm{i}$ & $\mathrm{f}$ & $\mathrm{r}$ & M & $\mathrm{i}$ & $\mathrm{f}$ & $r$ & $\mathrm{i}$ & $\mathrm{f}$ & $\mathrm{M}$ & $r$ & M & $\mathrm{i}$ & f & $\mathrm{r}$ \\
\hline & & 0.008 & 0.011 & 0.012 & 0.07 & 0.007 & 0.008 & 0.009 & 0.056 & $9 \mathrm{e}-4$ & $9 \mathrm{e}-4$ & $2 e-3$ & $4 \mathrm{e}-3$ & 0.004 & 0.007 & 0.008 & 0.044 \\
\hline \multirow{2}{*}{2} & \multirow{2}{*}{1.015} & $\mathrm{f}$ & $\mathrm{M}$ & $\mathrm{i}$ & $\mathrm{r}$ & $\mathrm{f}$ & $\mathrm{M}$ & $\mathrm{i}$ & $\mathrm{r}$ & $\mathrm{f}$ & $\mathrm{i}$ & $\mathrm{r}$ & M & $\mathrm{f}$ & $\mathrm{M}$ & $\mathrm{i}$ & $\mathrm{r}$ \\
\hline & & 0.033 & 0.033 & 0.033 & 0.043 & 0.03 & 0.03 & 0.03 & 0.037 & $1 \mathrm{e}-5$ & $2 e-5$ & $5 e-5$ & $2 \mathrm{e}-4$ & 0.015 & 0.016 & 0.016 & 0.023 \\
\hline \multirow{2}{*}{2} & \multirow[t]{2}{*}{4} & $\mathrm{f}$ & $\mathrm{i}$ & $\mathrm{M}$ & $\mathrm{r}$ & $\mathrm{f}$ & M & $\mathrm{i}$ & $\mathrm{r}$ & $\mathrm{i}$ & $\mathrm{f}$ & M & $r$ & $\mathrm{f}$ & $\mathrm{i}$ & $\mathrm{M}$ & $\mathrm{r}$ \\
\hline & & 0.018 & 0.018 & 0.019 & 0.057 & 0.017 & 0.017 & 0.017 & 0.048 & $5 e-4$ & $6 e-4$ & $1 \mathrm{e}-3$ & $2 \mathrm{e}-3$ & 0.006 & 0.006 & 0.007 & 0.03 \\
\hline \multirow{2}{*}{4} & \multirow{2}{*}{1.015} & $\mathrm{f}$ & $\mathrm{M}$ & $\mathrm{i}$ & $r$ & $\mathrm{f}$ & $\mathrm{M}$ & $\mathrm{i}$ & $\mathrm{r}$ & $\mathrm{i}$ & $\mathrm{f}$ & $\mathrm{r}$ & $\mathrm{M}$ & $\mathrm{f}$ & $\mathrm{M}$ & $\mathrm{i}$ & $\mathrm{r}$ \\
\hline & & 0.036 & 0.036 & 0.036 & 0.04 & 0.031 & 0,031 & 0.032 & 0.035 & $8 \mathrm{e}-6$ & $8 \mathrm{e}-6$ & $3 e-5$ & $1 \mathrm{e}-4$ & 0.017 & 0.017 & 0.017 & 0,021 \\
\hline \multirow{2}{*}{4} & \multirow{2}{*}{4} & $\mathrm{f}$ & $\mathrm{M}$ & $\mathrm{i}$ & $\mathrm{r}$ & f & $\mathrm{M}$ & $\mathrm{i}$ & $\mathrm{r}$ & $\mathrm{i}$ & $\mathrm{f}$ & $\mathrm{M}$ & $r$ & $\mathrm{f}$ & $\mathrm{i}$ & M & $\mathrm{r}$ \\
\hline & & 0.031 & 0.031 & 0.031 & 0.049 & 0.028 & 0.028 & 0.028 & 0.043 & $4 e-4$ & $4 \mathrm{e}-4$ & $5 e-4$ & $9 \mathrm{e}-4$ & 0.013 & 0.013 & 0.013 & 0.024 \\
\hline
\end{tabular}

In the cells we order the targeting procedures according to the calculated volatility. For example \begin{tabular}{|cccc|}
\hline $\mathrm{f}$ & $\mathrm{i}$ & $\mathrm{M}$ & $\mathrm{r}$ \\
0.002 & 0.002 & 0.002 & 0.019
\end{tabular} means that the lowest volatility is achieved for the f-targeting, then for the itargeting, M-targeting and the highest volatility is observed for the r-targeting. The numbers below state the standard error of the logarithm of the Hodrick-Prescott filtered series of the consumption for a given targeting procedure

To explain the volatility of the inflation rate, we have to look at the behavior of real balances. A variation in consumption is accompanied by an adjustment in the real balances. At the moment when the consumption takes place, the nominal balances are already chosen (in the financial exchange stage of the previous period). Therefore, real balances adjust via changes in prices. For a given set of parameter values, higher volatility of consumption implies in general a higher volatility of prices with the obvious exception of the inflation rate targeting. 
Table 3 Output growth rate volatility for the four targeting procedures; $\theta=$ relative risk aversion, $\bar{\mu}=$ average growth rate of money supply, $(A, s, G)=$ all three shocks are present, $(A)=$ only technology shocks are present, $(s)=$ only money demand shocks are present, $(G)=$ only government spending shocks are present

\begin{tabular}{|c|c|c|c|c|c|c|c|c|c|c|c|c|c|c|c|c|c|}
\hline \multirow[b]{2}{*}{$\theta$} & \multirow[b]{2}{*}{$\bar{\mu}$} & \multicolumn{16}{|c|}{ Growth rate volatility. Case with stochastic tax rate and no fiscal deficit } \\
\hline & & \multicolumn{4}{|c|}{$(A, s, G)$} & \multicolumn{4}{|c|}{$(A)$} & \multicolumn{4}{|c|}{$(s)$} & \multicolumn{4}{|c|}{$(G)$} \\
\hline \multirow{2}{*}{0.5} & & $\mathrm{f}$ & i & & & $\mathrm{f}$ & $\mathrm{i}$ & & & & $\mathrm{f}$ & $\mathrm{r}$ & & $\mathrm{f}$ & i & & $\mathrm{r}$ \\
\hline & 1.010 & 0.037 & 0.037 & 0.037 & 0.038 & 0.030 & 0.030 & 0.030 & 0.031 & $4 e-6$ & $4 e-6$ & $5 e-5$ & $2 e-5$ & 0.022 & 0.022 & 0.022 & 0.023 \\
\hline \multirow{2}{*}{0.5} & 4 & $\mathrm{f}$ & $\mathrm{i}$ & $\mathrm{M}$ & $\mathrm{r}$ & $\mathrm{f}$ & $\mathrm{i}$ & $\mathrm{M}$ & $\mathrm{r}$ & $\mathrm{i}$ & $\mathrm{f}$ & $\mathrm{M}$ & $\mathrm{r}$ & $\mathrm{f}$ & i & $\mathrm{M}$ & $\mathrm{r}$ \\
\hline & 4 & 0.037 & 0.037 & 0.037 & 0.039 & 0.030 & 0.030 & 0.030 & 0.031 & $8 e-7$ & $7 e-7$ & $4 \mathrm{e}-5$ & $4 \mathrm{e}-5$ & 0.022 & 0.022 & 0.022 & 0.023 \\
\hline \multirow{2}{*}{1} & & $\mathrm{f}$ & $\mathrm{i}$ & $\mathrm{M}$ & $\mathrm{r}$ & $\mathrm{f}$ & $\mathrm{i}$ & $\mathrm{M}$ & $\mathrm{r}$ & $\mathrm{i}$ & $\mathrm{f}$ & $\mathrm{r}$ & $\mathrm{M}$ & $\mathrm{f}$ & $\mathrm{i}$ & $\mathrm{M}$ & $\mathrm{r}$ \\
\hline & 1.015 & 0.038 & 0.038 & 0.038 & 0.038 & 0.030 & 0.030 & 0.030 & 0.031 & $2 \mathrm{e}-6$ & $2 \mathrm{e}-6$ & $1 e-5$ & $3 e-5$ & 0.022 & 0.022 & 0.022 & 0.022 \\
\hline \multirow{2}{*}{1} & 4 & $\mathrm{f}$ & $\mathrm{i}$ & $\mathrm{M}$ & $\mathrm{r}$ & $\mathrm{f}$ & $\mathrm{i}$ & $\mathrm{M}$ & $\mathrm{r}$ & $\mathrm{i}$ & $\mathrm{f}$ & $\mathrm{r}$ & $\mathrm{M}$ & $\mathrm{f}$ & $\mathrm{i}$ & $\mathrm{M}$ & $\mathrm{r}$ \\
\hline & & 0.038 & 0.038 & 0.038 & 0.039 & 0.030 & 0.030 & 0.030 & 0.031 & $5 \mathrm{e}-7$ & $6 e-7$ & $6 \mathrm{e}-6$ & $3 e-5$ & 0.022 & 0.022 & 0.022 & 0.023 \\
\hline \multirow{2}{*}{2} & & $\mathrm{f}$ & $\mathrm{M}$ & $\mathrm{i}$ & $\mathrm{r}$ & $\mathrm{f}$ & $\mathrm{M}$ & $\mathrm{i}$ & $\mathrm{r}$ & $\mathrm{i}$ & $\mathrm{f}$ & $\mathrm{r}$ & $\mathrm{M}$ & $\mathrm{f}$ & $\mathrm{M}$ & $\mathrm{i}$ & $\mathrm{r}$ \\
\hline & 1.015 & 0.038 & 0.038 & 0.038 & 0.038 & 0.030 & 0.030 & 0.030 & 0.031 & $2 \mathrm{e}-6$ & $2 e-6$ & $6 \mathrm{e}-6$ & $2 \mathrm{e}-5$ & 0.022 & 0.022 & 0.022 & 0.022 \\
\hline \multirow{2}{*}{2} & 4 & $\mathrm{f}$ & $\mathrm{M}$ & $\mathrm{i}$ & $\mathrm{r}$ & $\mathrm{f}$ & $\mathrm{M}$ & $\mathrm{i}$ & $\mathrm{r}$ & $\mathrm{i}$ & $\mathrm{f}$ & $\mathrm{r}$ & $\mathrm{M}$ & $\mathrm{f}$ & $\mathrm{i}$ & $\mathrm{M}$ & $r$ \\
\hline & & 0.038 & 0.038 & 0.038 & 0.038 & 0.030 & 0.030 & 0.030 & 0.031 & $4 \mathrm{e}-7$ & $4 e-7$ & $2 \mathrm{e}-6$ & $2 \mathrm{e}-5$ & 0.022 & 0.022 & 0.022 & 0.022 \\
\hline \multirow{2}{*}{4} & 1015 & $\mathrm{f}$ & $\mathrm{M}$ & $\mathrm{i}$ & $\mathrm{r}$ & $\mathrm{f}$ & $\mathrm{M}$ & $\mathrm{i}$ & $\mathrm{r}$ & $\mathrm{i}$ & $\mathrm{f}$ & $\mathrm{r}$ & $\mathrm{M}$ & $\mathrm{f}$ & $\mathrm{M}$ & i & $\mathrm{r}$ \\
\hline & 1.010 & 0.038 & 0.038 & 0.038 & 0.038 & 0.031 & 0.031 & 0.031 & 0.031 & $2 \mathrm{e}-6$ & $2 \mathrm{e}-6$ & $4 \mathrm{e}-6$ & $1 \mathrm{e}-5$ & 0.022 & 0.022 & 0.022 & 0.022 \\
\hline \multirow{2}{*}{4} & 4 & $\mathrm{f}$ & $\mathrm{M}$ & $\mathrm{i}$ & $\mathrm{r}$ & $\mathrm{f}$ & $\mathrm{M}$ & $\mathrm{i}$ & $\mathrm{r}$ & $\mathrm{i}$ & $\mathrm{f}$ & $\mathrm{r}$ & $\mathrm{M}$ & $\mathrm{f}$ & $\mathrm{M}$ & i & $\mathrm{r}$ \\
\hline & 4 & 0.038 & 0.038 & 0.038 & 0.038 & 0.031 & 0.031 & 0.031 & 0.031 & $4 \mathrm{e}-7$ & $4 e-7$ & $1 \mathrm{e}-6$ & $1 e-5$ & 0.022 & 0.022 & 0.022 & 0.022 \\
\hline
\end{tabular}

\begin{tabular}{|c|c|c|c|c|c|c|c|c|c|c|c|c|c|c|c|c|c|}
\hline \multirow[b]{2}{*}{$\theta$} & \multirow[b]{2}{*}{$\bar{\mu}$} & \multicolumn{16}{|c|}{ Growth rate volatility. Case with constant tax rate and stochastic fiscal deficit } \\
\hline & & \multicolumn{4}{|c|}{$(A, s, G)$} & \multicolumn{4}{|c|}{$(A)$} & \multicolumn{4}{|c|}{$(s)$} & \multicolumn{4}{|c|}{$(G)$} \\
\hline \multirow[b]{2}{*}{0.5} & & $\mathrm{f}$ & $\mathrm{i}$ & & $\mathrm{r}$ & $\mathrm{f}$ & $\mathrm{i}$ & & $\mathrm{r}$ & & $\mathrm{f}$ & $\mathrm{r}$ & & $\mathrm{f}$ & $\mathrm{i}$ & & $\mathrm{r}$ \\
\hline & 1.015 & 0.037 & 0.037 & 0.037 & 0.039 & 0.030 & 0.030 & 0.030 & 0.031 & $1 \mathrm{e}-6$ & $1 e-6$ & $9 \mathrm{e}-6$ & $5 e-5$ & 0.022 & 0.022 & 0.022 & 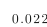 \\
\hline \multirow{2}{*}{0.5} & & $\mathrm{f}$ & $\mathrm{i}$ & $\mathrm{M}$ & $\mathrm{r}$ & M & $\mathrm{f}$ & $\mathrm{i}$ & $\mathrm{r}$ & $\mathrm{i}$ & f & $\mathrm{r}$ & $\mathrm{M}$ & $\mathrm{M}$ & $\mathrm{f}$ & $\mathrm{i}$ & $\mathrm{r}$ \\
\hline & 4 & 0.037 & 0.037 & 0.037 & 0.039 & 0.030 & 0.030 & 0.030 & 0.031 & $1 \mathrm{e}-6$ & $1 \mathrm{e}-6$ & $9 \mathrm{e}-6$ & $7 e-5$ & 0.022 & 0.022 & 0.022 & 0.023 \\
\hline \multirow{2}{*}{1} & & $\mathrm{f}$ & $\mathrm{i}$ & $\mathrm{M}$ & $\mathrm{r}$ & $f$ & $\mathrm{i}$ & $\mathrm{M}$ & $\mathrm{r}$ & $\mathrm{i}$ & $\mathrm{f}$ & $\mathrm{r}$ & $\mathrm{M}$ & $\mathrm{f}$ & $\mathrm{i}$ & $\mathrm{M}$ & $\mathrm{r}$ \\
\hline & 1.010 & 0.038 & 0.038 & 0.038 & 0.038 & 0.030 & 0.030 & 0.030 & 0.031 & $9 \mathrm{c}-7$ & $9 e-7$ & $5 \mathrm{e}-6$ & $3 e-5$ & 0.022 & 0.022 & 0.022 & 0.022 \\
\hline \multirow{2}{*}{1} & 4 & $\mathrm{M}$ & $\mathrm{f}$ & $\mathrm{i}$ & $\mathrm{r}$ & $\mathrm{M}$ & $\mathrm{f}$ & $\mathrm{i}$ & $\mathrm{r}$ & $\mathrm{i}$ & $\mathrm{f}$ & $\mathrm{r}$ & $\mathrm{M}$ & $\mathrm{M}$ & $\mathrm{f}$ & $\mathrm{i}$ & $\mathrm{r}$ \\
\hline & & 0.037 & 0.038 & 0.038 & 0.038 & 0.030 & 0.030 & 0.030 & 0.031 & $9 e-7$ & $9 \mathrm{e}-7$ & $5 \mathrm{e}-6$ & $5 e-5$ & 0.022 & 0.022 & 0.022 & 0.022 \\
\hline \multirow{2}{*}{2} & & $\mathrm{f}$ & $\mathrm{M}$ & $\mathrm{i}$ & $\mathrm{r}$ & $\mathrm{f}$ & $\mathrm{M}$ & $\mathrm{i}$ & $\mathrm{r}$ & $\mathrm{i}$ & $\mathrm{f}$ & $\mathrm{r}$ & $\mathrm{M}$ & $f$ & $\mathrm{M}$ & i & $\mathrm{r}$ \\
\hline & 1.015 & 0.038 & 0.038 & 0.038 & 0.038 & 0.030 & 0.030 & 0.030 & 0.031 & $7 \mathrm{e}-7$ & $7 \mathrm{e}-7$ & $3 \mathrm{e}-6$ & $2 e-5$ & 0.022 & 0.022 & 0.022 & 0.022 \\
\hline \multirow{2}{*}{2} & 4 & $\mathrm{M}$ & $\mathrm{f}$ & $\overline{\mathrm{i}}$ & $\mathrm{r}$ & $\mathrm{M}$ & $f$ & $\overline{\mathrm{i}}$ & $\mathrm{r}$ & & $\mathrm{f}$ & $\mathrm{r}$ & $\mathrm{M}$ & $\mathrm{M}$ & $\mathrm{f}$ & $\mathrm{i}$ & $\mathrm{r}$ \\
\hline & & 0.038 & 0.038 & 0.038 & 0.038 & 0.030 & 0.030 & 0.030 & 0.031 & $7 e-7$ & $7 e-7$ & $3 e-6$ & $3 e-5$ & 0.022 & 0.022 & 0.022 & 0.022 \\
\hline \multirow{2}{*}{4} & 1015 & $\mathrm{f}$ & $\mathrm{M}$ & $\mathrm{i}$ & $\mathrm{r}$ & $\mathrm{f}$ & $\mathrm{M}$ & $\mathrm{i}$ & $\mathrm{r}$ & $\mathrm{i}$ & $\mathrm{f}$ & $\mathrm{r}$ & $\mathrm{M}$ & $\mathrm{f}$ & $\mathrm{M}$ & $\mathrm{i}$ & $\mathrm{r}$ \\
\hline & 1.010 & 0.038 & 0.038 & 0.038 & 0.038 & 0.031 & 0.031 & 0.031 & 0.031 & $7 e-7$ & $8 e-7$ & $3 e-6$ & $1 e-5$ & 0.022 & 0.022 & 0.022 & 0.022 \\
\hline \multirow{2}{*}{4} & 4 & $\mathrm{M}$ & $\mathrm{f}$ & $\mathrm{i}$ & $\mathrm{r}$ & $\mathrm{M}$ & $\mathrm{f}$ & $\mathrm{i}$ & $\mathrm{r}$ & $\mathrm{i}$ & $\mathrm{f}$ & $\mathrm{r}$ & $\mathrm{M}$ & $\mathrm{M}$ & $\mathrm{f}$ & $\mathrm{i}$ & $\mathrm{r}$ \\
\hline & & 0.038 & 0.038 & 0.038 & 0.038 & 0.031 & 0.031 & 0.031 & 0.031 & $7 e-7$ & $8 e-7$ & $3 e-6$ & $2 e-5$ & 0.022 & 0.022 & 0.022 & 0.022 \\
\hline
\end{tabular}

In the cells we order the targeting procedures according to the calculated volatility. For example \begin{tabular}{|cccc|}
\hline $\mathrm{f}$ & $\mathrm{M}$ & $\mathrm{i}$ & $\mathrm{r}$ \\
0.037 & 0.037 & 0.037 & 0.038
\end{tabular} means that the lowest volatility is achieved for the f-targeting, then for the Mtargeting, i-targeting and the highest volatility is observed for the r-targeting. The numbers below state the standard error of the logarithm of the Hodrick-Prescott filtered series of the growth rate of output for a given targeting procedure

The ordering of targeting procedures according to the volatilities does not vary for different risk aversion parameters, neither for different levels of seigniorage. Moreover, we can see from the production function (5) and (9) that $\frac{d y_{t}}{d A_{t}}=\frac{1}{\alpha}$ and $\frac{d y_{t}}{d G_{t}}=\frac{1-\alpha}{\alpha}$. As $\frac{1}{\alpha}>\frac{1-\alpha}{\alpha}$, we obtain that the contribution of technology shocks is more important than the one of government spending shocks. Finally, the impact of money demand shocks on the overall volatility of all three analyzed variables is negligible. 
Table 4 Inflation rate volatility for the four targeting procedures; $\theta=$ relative risk aversion, $\bar{\mu}=$ average growth rate of money supply, $(A, s, G)=$ all three shocks are present, $(A)=$ only technology shocks are present, $(s)=$ only money demand shocks are present, $(G)=$ only government spending shocks are present

\begin{tabular}{|c|c|c|c|c|c|c|c|c|c|c|c|c|c|c|}
\hline \multirow[b]{2}{*}{$\theta$} & \multirow[b]{2}{*}{$\bar{\mu}$} & \multicolumn{13}{|c|}{ Inflation rate volatility. Case with stochastic tax rate and no fiscal deficit } \\
\hline & & \multicolumn{4}{|c|}{$(A, s, G)$} & \multicolumn{3}{|c|}{$(A)$} & \multicolumn{3}{|c|}{$(s)$} & \multicolumn{3}{|c|}{$(G)$} \\
\hline \multirow{2}{*}{0.5} & \multirow{2}{*}{1.015} & $\mathrm{f}$ & M & i & $\mathrm{r}$ & f $\mathrm{M}$ & $\mathrm{i}$ & $\mathrm{r}$ & f i & $\mathrm{r}$ & & f $\mathrm{M}$ & $\mathrm{i}$ & \\
\hline & & 0 & 0.002 & 0.004 & 0.08 & $0 \quad 0.001$ & 0.003 & 0.067 & $2 \mathrm{e}-5$ & $4 \mathrm{e}-4$ & 0.001 & $\begin{array}{ll}0 & 0.001 \\
\end{array}$ & 0.002 & 0.04 \\
\hline \multirow{2}{*}{0.5} & \multirow{2}{*}{4} & $\mathrm{f}$ & $\mathrm{i}$ & $\mathrm{M}$ & $\mathrm{r}$ & $\begin{array}{ll}f & i\end{array}$ & $\mathrm{M}$ & $\mathrm{r}$ & $f$ & $\mathrm{M}$ & $\mathrm{r}$ & $f$ & $\mathrm{M}$ & $\mathrm{r}$ \\
\hline & & 0 & 0.004 & 0.015 & 1.32 & $\begin{array}{ll}0 & 0.003\end{array}$ & 0.008 & 0.69 & $\begin{array}{ll}0 & 6 \mathrm{e}-6\end{array}$ & 0.007 & 0.007 & $\begin{array}{ll}0 & 0.002\end{array}$ & 0.011 & 0.80 \\
\hline \multirow{2}{*}{1} & \multirow{2}{*}{1.015} & $\mathrm{f}$ & & & $\mathrm{r}$ & f i & $\mathrm{M}$ & $\mathrm{r}$ & f i & $\mathrm{r}$ & & $\mathrm{f} \quad \mathrm{i}$ & $\mathrm{M}$ & \\
\hline & & 0 & $9 \mathrm{e}-4$ & 0.002 & 0.07 & $\begin{array}{ll}0 & 7 \mathrm{e}-4\end{array}$ & $8 \mathrm{e}-4$ & 0.063 & $0 \quad 5 e-6$ & $4 e-4$ & 0.001 & $\begin{array}{l}0 \\
\end{array}$ & $8 e-4$ & 0.04 \\
\hline \multirow{2}{*}{1} & \multirow{2}{*}{4} & $\mathrm{f}$ & $\mathrm{M}$ & $\mathrm{i}$ & $\mathrm{r}$ & $\begin{array}{ll}f & M\end{array}$ & $\mathrm{i}$ & $\mathrm{r}$ & $\begin{array}{ll}f & i\end{array}$ & $\mathrm{r}$ & $\mathrm{M}$ & $\begin{array}{ll}f & M\end{array}$ & i & \\
\hline & & 0 & 0.011 & 0.016 & 0.72 & $\begin{array}{ll}0 & 0.005 \\
\end{array}$ & 0.013 & 0.53 & $\begin{array}{ll}0 & 3 \mathrm{e}-5 \\
\end{array}$ & 0.002 & 0.007 & $\begin{array}{ll}0 & 0.007 \\
\end{array}$ & 0.009 & 0.38 \\
\hline \multirow{2}{*}{2} & \multirow{2}{*}{1.015} & $\mathrm{f}$ & i & $\mathrm{M}$ & $\mathrm{r}$ & f $\quad M$ & $\mathrm{i}$ & $r$ & $\begin{array}{ll}\mathrm{f} & \mathrm{i}\end{array}$ & $r$ & $\mathrm{M}$ & $\begin{array}{ll}\mathrm{f} & \mathrm{M}\end{array}$ & $\mathrm{i}$ & $\mathrm{r}$ \\
\hline & & 0 & 0.001 & 0.001 & 0.07 & $0 \quad 5 \mathrm{e}-4$ & $9 \mathrm{e}-4$ & 0.057 & $\begin{array}{ll}0 & 7 \mathrm{e}-6 \\
\end{array}$ & $4 \mathrm{e}-4$ & 0.001 & $\begin{array}{l}0 \\
0\end{array}$ & $6 \mathrm{e}-4$ & 0.037 \\
\hline \multirow{2}{*}{2} & \multirow{2}{*}{4} & $\mathrm{f}$ & $\mathrm{i}$ & $\mathrm{M}$ & $\mathrm{r}$ & $\mathrm{M}$ & i & $\mathrm{r}$ & $\begin{array}{ll}\mathrm{f} & \mathrm{i}\end{array}$ & $\mathrm{r}$ & $\mathrm{M}$ & f i & $\mathrm{M}$ & $\mathrm{r}$ \\
\hline & & 0 & 0.006 & 0.009 & 0.53 & $\begin{array}{ll}0 & 0.003 \\
\end{array}$ & 0.005 & 0.43 & $\begin{array}{ll}0 & 2 \mathrm{e}-5 \\
\end{array}$ & 0.001 & 0.007 & $\begin{array}{ll}0 & 0.003 \\
\end{array}$ & 0.004 & 0.27 \\
\hline \multirow{2}{*}{4} & \multirow{2}{*}{1.015} & $\mathrm{f}$ & $\mathrm{M}$ & $\mathrm{i}$ & $\mathrm{r}$ & $\begin{array}{ll}f & M\end{array}$ & $\mathrm{i}$ & $\mathrm{r}$ & f i & $\mathrm{r}$ & $\mathrm{M}$ & $\begin{array}{ll}\mathrm{f} & \mathrm{M}\end{array}$ & $\mathrm{i}$ & $\mathrm{r}$ \\
\hline & & 0 & 0.001 & 0.001 & 0.06 & $\begin{array}{ll}0 & 3 \mathrm{e}-4 \\
\end{array}$ & 0.001 & 0.051 & $\begin{array}{ll}0 & 1 \mathrm{e}-5 \\
\end{array}$ & $5 e-4$ & 0.001 & $\begin{array}{ll}0 & 3 \mathrm{e}-4 \\
\end{array}$ & $8 \mathrm{e}-4$ & 0.032 \\
\hline \multirow{2}{*}{4} & \multirow{2}{*}{4} & $\mathrm{f}$ & $\mathrm{M}$ & $\mathrm{i}$ & $\mathrm{r}$ & f $\quad M$ & $\mathrm{i}$ & $\mathrm{r}$ & $\begin{array}{ll} & i\end{array}$ & $\mathrm{r}$ & & $\begin{array}{ll}\mathrm{f} & \mathrm{M}\end{array}$ & i & $\mathrm{r}$ \\
\hline & & 0 & 0.007 & 0.009 & 0.4 & 0.002 & 0.007 & 0.34 & $3 e-5$ & 0.001 & 0.007 & 0.002 & 0.005 & 0.20 \\
\hline
\end{tabular}

\begin{tabular}{|c|c|c|c|c|c|c|c|c|c|c|c|c|c|c|c|}
\hline \multirow[b]{2}{*}{$\theta$} & \multirow[b]{2}{*}{$\bar{\mu}$} & \multicolumn{14}{|c|}{ Inflation rate volatility. Case with constant tax rate and stochastic fiscal deficit } \\
\hline & & \multicolumn{4}{|c|}{$(A, s, G)$} & \multicolumn{4}{|c|}{$(A)$} & \multicolumn{3}{|c|}{$(s)$} & \multicolumn{3}{|c|}{$(G)$} \\
\hline \multirow{2}{*}{0.5} & \multirow{2}{*}{1.015} & $\mathrm{f}$ & & $\mathrm{M}$ & $\mathrm{r}$ & $\mathrm{f}$ & $\mathrm{i}$ & $\mathrm{M}$ & $\mathrm{r}$ & f $\mathrm{i}$ & $\mathrm{r}$ & $\mathrm{M}$ & f i & $\mathrm{M}$ & $\mathrm{r}$ \\
\hline & & 0 & $8 \mathrm{e}-4$ & 0.002 & 0.12 & 0 & $7 \mathrm{e}-4$ & 0.001 & 0.09 & $\begin{array}{ll}0 & 2 \mathrm{e}-6\end{array}$ & $2 \mathrm{e}-4$ & 0.001 & $\begin{array}{ll}0 & 5 \mathrm{e}-4\end{array}$ & 0.002 & 0.07 \\
\hline \multirow{2}{*}{0.5} & \multirow{2}{*}{4} & t & i & & $\mathrm{r}$ & $\mathrm{f}$ & i & $\mathrm{M}$ & $\mathrm{r}$ & $\begin{array}{ll}\mathrm{f} & \mathrm{i}\end{array}$ & $\mathrm{M}$ & $\mathrm{r}$ & $\begin{array}{ll}\mathrm{f} & \mathrm{i}\end{array}$ & $\mathrm{M}$ & $\mathrm{r}$ \\
\hline & & 0 & $6 \mathrm{e}-3$ & 0.05 & 0.71 & 0 & $5 e-3$ & 0.02 & 0.53 & $\begin{array}{ll}0 & 2 \mathrm{c}-4 \\
\end{array}$ & 0.01 & 0.02 & $\begin{array}{ll}0 & 3 \mathrm{e}-3 \\
\end{array}$ & 0.04 & 0.36 \\
\hline \multirow{2}{*}{1} & \multirow{2}{*}{1.015} & $\mathrm{f}$ & $\mathrm{i}$ & $\mathrm{M}$ & & $f$ & $\mathrm{i}$ & $\mathrm{M}$ & $\mathrm{r}$ & $\begin{array}{ll}f & i\end{array}$ & $\mathrm{r}$ & $\mathrm{M}$ & $\mathrm{f}$ & $\mathrm{M}$ & $\mathrm{r}$ \\
\hline & & 0 & $9 \mathrm{e}-4$ & 0.002 & 0.11 & 0 & $7 \mathrm{e}-4$ & $8 \mathrm{e}-4$ & 0.09 & $\begin{array}{ll}0 & 2 \mathrm{e}-6\end{array}$ & $2 \mathrm{e}-4$ & 0.001 & $\begin{array}{ll}0 & 5 \mathrm{e}-4\end{array}$ & $9 \mathrm{e}-4$ & 0.06 \\
\hline \multirow{2}{*}{1} & \multirow{2}{*}{4} & & $\mathrm{i}$ & & & $f$ & $\mathrm{i}$ & $\mathrm{M}$ & $\mathrm{r}$ & $\begin{array}{ll}f & i\end{array}$ & $\mathrm{M}$ & & $\mathrm{f}$ & $\mathrm{M}$ & $\mathrm{r}$ \\
\hline & & 0 & $6 e-3$ & 0.031 & 0.63 & 0 & $5 \mathrm{e}-3$ & 0.01 & 0.48 & $\begin{array}{ll}0 & 3 \mathrm{e}-4 \\
\end{array}$ & 0.02 & 0.03 & $4 \mathrm{e}-3$ & 0.02 & 0.33 \\
\hline \multirow{2}{*}{2} & \multirow{2}{*}{1.015} & $\mathrm{f}$ & $\mathrm{i}$ & & & $f$ & $\mathrm{M}$ & $\mathrm{i}$ & $\mathrm{r}$ & $\begin{array}{ll}f & i\end{array}$ & $\mathrm{r}$ & & $\begin{array}{ll}\mathrm{f} & \mathrm{M}\end{array}$ & $\mathrm{i}$ & $\mathrm{r}$ \\
\hline & & 0 & 0.001 & 0.001 & 0.1 & 0 & $4 e-4$ & $9 \mathrm{e}-4$ & 0.08 & $0 \quad 3 \mathrm{e}-6$ & $3 e-4$ & 0.001 & $6 \mathrm{e}-4$ & $6 e-4$ & 0.06 \\
\hline \multirow{2}{*}{2} & & & $\mathrm{i}$ & & & f & $\mathrm{M}$ & & $\mathrm{r}$ & $\begin{array}{ll}f & i\end{array}$ & $\mathrm{M}$ & & f i & $\mathrm{M}$ & $\mathrm{r}$ \\
\hline & & & $7 e-3$ & 0.02 & 0.54 & 0 & $5 e-3$ & $5 e-3$ & 0.41 & $\begin{array}{ll}0 & 4 \mathrm{e}-4 \\
\end{array}$ & 0.02 & 0.03 & $0 \quad 4 \mathrm{e}-3$ & 0.01 & 0.29 \\
\hline \multirow{2}{*}{4} & \multirow{2}{*}{1.015} & & $\mathrm{M}$ & & & $\mathrm{f}$ & $\mathrm{M}$ & $\mathrm{i}$ & $\mathrm{r}$ & f i & $r$ & $\mathrm{M}$ & $\begin{array}{ll}\mathrm{f} & \mathrm{M}\end{array}$ & $\mathrm{i}$ & $\mathrm{r}$ \\
\hline & & 0 & 0.001 & 0.001 & 0.09 & 0 & $3 \mathrm{e}-4$ & 0.001 & 0.07 & $0 \quad 5 \mathrm{e}-6$ & $3 \mathrm{e}-4$ & 0.001 & $3 \mathrm{e}-4$ & $8 \mathrm{e}-4$ & 0.05 \\
\hline \multirow{2}{*}{4} & & & $\mathrm{i}$ & $\mathrm{M}$ & $\mathrm{r}$ & $\mathrm{f}$ & $\mathrm{M}$ & i & $\mathrm{r}$ & $\begin{array}{ll}\mathrm{f} & \mathrm{i}\end{array}$ & $\mathrm{M}$ & $\mathrm{r}$ & $\mathrm{f}$ & $\mathrm{M}$ & $\mathrm{r}$ \\
\hline & & & 0.008 & 0.02 & 0.44 & 0 & 0.002 & 0.007 & 0.34 & $\begin{array}{ll}0 & 6 \mathrm{e}-4\end{array}$ & 0.02 & 0.03 & $5 e-3$ & 0.008 & 0.24 \\
\hline
\end{tabular}

In the cells we order the targeting procedures according to the calculated volatility. For example \begin{tabular}{|cccc|}
\hline $\mathrm{f}$ & $\mathrm{i}$ & $\mathrm{M}$ & $\mathrm{r}$ \\
0 & $9 \mathrm{e}-4$ & 0.002 & 0.075
\end{tabular} means that the lowest volatility is achieved for the f-targeting, then for the i-targeting, M-targeting and the highest volatility is observed for the r-targeting. The numbers below state the standard error of the logarithm of the Hodrick-Prescott filtered series of the inflation rate for a given targeting procedure

\subsubsection{Welfare}

In order to asses the welfare implications of the different targeting instruments of monetary policy, we should evaluate the welfare of the representative agent, which is given by 


$$
W=E_{0}\left[\sum_{t=0}^{\infty} \beta^{t}\left(\frac{c_{t}^{1-\theta}-1}{1-\theta}\right)\right]
$$

To this end we calculate the welfare as an empirical mean of 1000 shock realizations of time series with a horizon of 1500 periods.

We again let the origin of disturbances be all three kinds of shocks, only technology shocks, only money demand shocks, and only government spending shocks. We choose the inflation rate targeting to be a reference policy. We evaluate welfare differences as a percentage of consumption which must be added, or subtracted, in order to obtain the same welfare as under the reference policy. We thus look for the value $\epsilon$ that fulfills

$$
E_{0}\left\{\sum_{t=0}^{\infty} \beta^{t}\left[\frac{(1+\epsilon) c_{t}^{1-\theta}-1}{1-\theta}\right]\right\}=E_{0}\left\{\sum_{t=0}^{\infty} \beta^{t}\left[\frac{\left(c_{t}^{\mathrm{f} \text {-targeting }}\right)^{1-\theta}-1}{1-\theta}\right]\right\}
$$

where $\left\{c_{t}^{\mathrm{f} \text {-targeting }}\right\}_{t=0}^{\infty}$ is the consumption path obtained under the inflation rate targeting. Targeting procedures are ordered according to the welfare so achieved. Positive numbers for $\epsilon$ mean that, in order to obtain the same welfare level as under the f-targeting, the percentage $\epsilon$ of consumption given in Table 5 must be added to the original consumption in every period. Negative numbers mean that, if agents reduce that much percentage of their consumption, they would obtain the same welfare as under the inflation rate targeting. Results are reported in Table 5.

In order to explain the welfare differences it is important to look at the behavior of consumption over a long period of time as the frequency of fluctuations has crucial implications for welfare. Short-run volatility of consumption turns out to be not so important for welfare. We plot the evolution of consumption under the f-targeting and r-targeting when the economy is hit by a random sequence of technology shocks for different levels of risk aversion and for the two fiscal scenarios under consideration in Fig. 4. We can observe that, as the agents become more risk averse, they want to smooth their lifetime consumption path and the deviations from the non-stochastic trend decrease. As we have already argued, under the r-targeting technological shocks have a strong effect on consumption and a much moderate effect on capital accumulation. Therefore, under this procedure the path of capital is very smooth. The long-run fluctuation of capital is inherited also by the other variables, like consumption, output, and government spending. Thus, all the other variables fluctuate in the short run close to their non-stochastic long-run trend. Under the f-targeting the real interest rate fluctuates and, hence, the path of capital and other variables exhibits deviations from the non-stochastic trend that are much larger in the long run. Therefore, very risk averse agents obtain on average higher welfare when their consumption does not deviate much from its non-stochastic long-run trend. This means that the r-targeting is the procedure that delivers the highest welfare when risk aversion is high. However, very high deviations from the long-run trend may result in welfare gains under low risk aversion since now agents care mainly about their consumption in the short run. Thus, depending on the actual sequence of shocks the r-targeting may be dominated by other 
Table 5 Differences in welfare levels achieved under the four targeting procedures; $\theta=$ relative risk aversion, $\bar{\mu}=$ average growth rate of money supply, $(A, s, G)=$ all three shocks are present, $(A)=$ only technology shocks are present, $(s)=$ only money demand shocks are present, $(G)=$ only government spending shocks are present

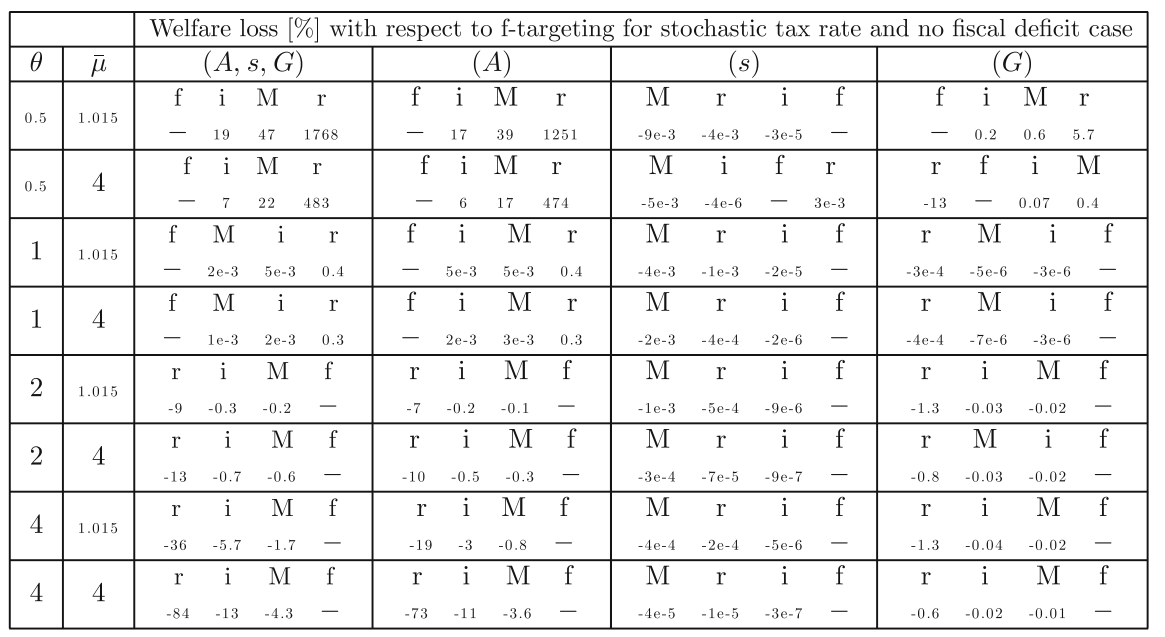

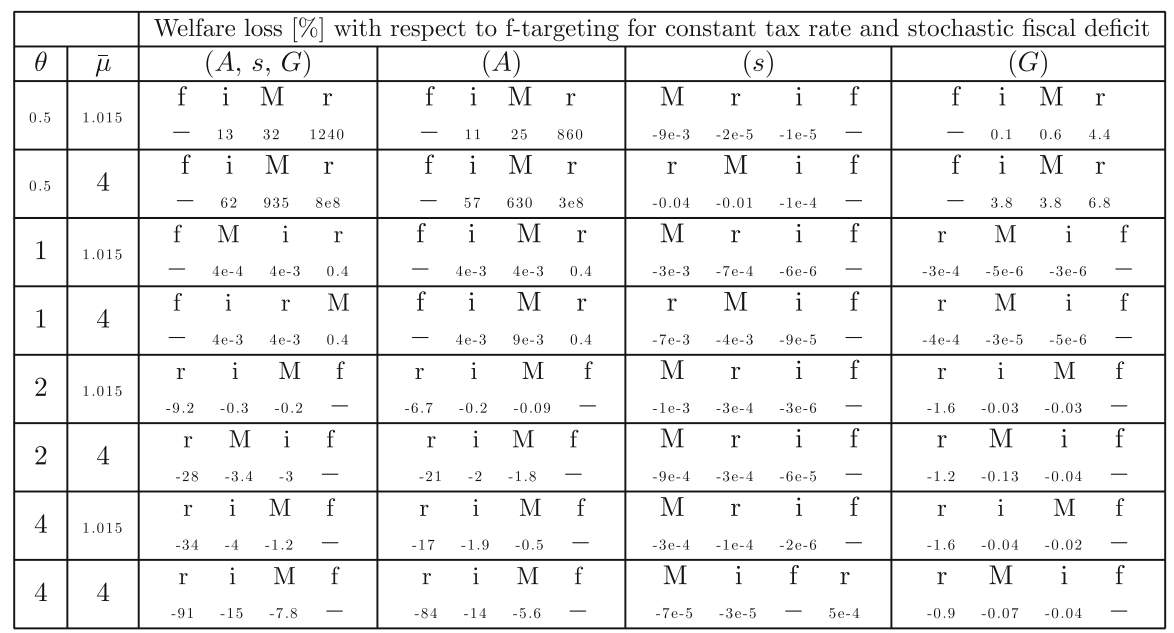

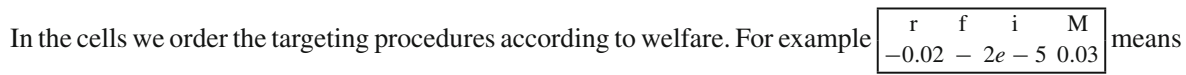
that the highest welfare is achieved for the r-targeting, then for the f-targeting, i-targeting, and the lowest welfare is observed for the M-targeting. The numbers below give the welfare loss (or gain when negative) for a given targeting procedure with respect to the inflation targeting

targeting procedures. Averaging over 1000 shock realizations (which are the same for all parameters presented in Table 5) the i-targeting is ranked as the second concerning welfare, just after the $\mathrm{r}$-targeting when the risk aversion parameter $\theta$ is high (see Table 5). However, when $\theta$ is low, our simulations show that the f-targeting is the procedure that delivers the highest level of welfare. 

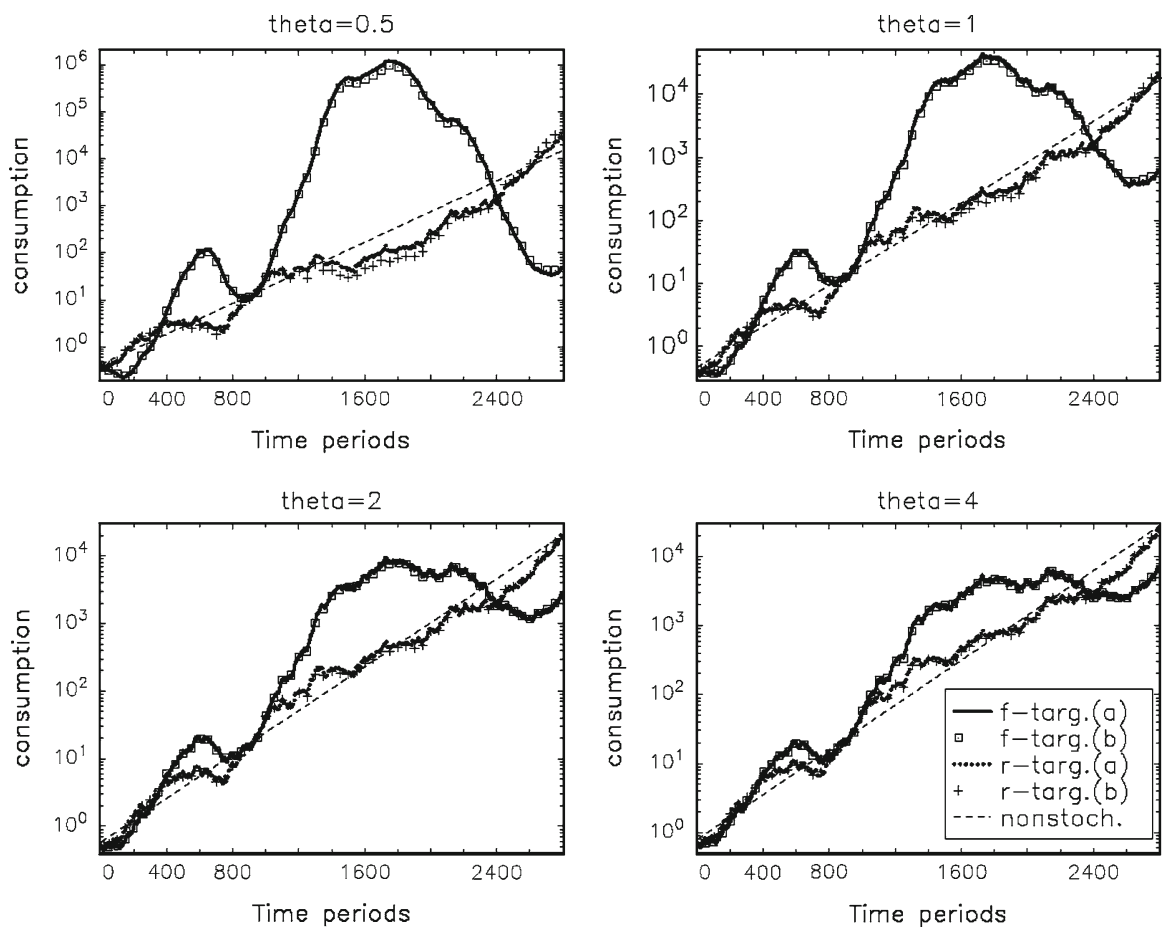

Fig. 4 Evolution of consumption over time in an economy hit by a random sequence of technology shocks under the f-targeting and r-targeting for $\theta=0.5,1,2$ and 4 . The case (a) corresponds to the fiscal scenario with stochastic tax rate and no fiscal deficit, while the case (b) corresponds to the fiscal scenario with constant tax rate and stochastic fiscal deficit

We can also see in Table 5 that for the logarithmic utility function $(\theta=1)$ the differences between the M-targeting, i-targeting and f-targeting are negligible, as they are up to $0.005 \%$ of the stream of consumption. However, these differences get larger when the value of $\theta$ is set away (either above or below) from 1. For instance, for $\theta=4$ they might take values close to $5 \%$.

Under the money demand shocks the M-targeting delivers the highest welfare. Again, the consumption series are very similar for all targeting procedures and the differences are much smaller since they amount just up to $0.01 \%$ of the stream of consumption.

Under the government spending shocks the behavior of the welfare is again similar to the case when only technology shocks occur. For $\theta<1$ the f-targeting leads to the highest welfare, whereas for $\theta>1$ it is the r-targeting the one that delivers more welfare. For example, the model implies that for $\theta=2$ and $\bar{\mu}=1.015$, a switch from the inflation rate targeting to the real interest rate targeting would on average produce a gain equivalent to the $1.5 \%$ in the stream of consumption of agents.

We can summarize the main implication of our previous analysis by saying that under high risk aversion and real shocks (i.e., either technological or government shocks), to target the real interest rate is the procedure that yields a higher expected welfare. 


\section{Final Remarks}

In this paper we have analyzed the effects of four targeting procedures of monetary policy in an economy where the government uses money creation to finance productive public spending. We have studied how the endogenous variables react to unexpected transitory shocks and we have shown the contribution of the three particular shocks to the fluctuations of the growth rate, inflation rate, and consumption. We have compared welfare levels obtained under four particular targeting procedures and two alternative fiscal policies (constant real government debt versus constant tax rates). We should mention that we have considered a new targeting procedure in our analysis, namely, the real interest targeting, which is in fact used indirectly by some central banks that have an inflation rate objective and control the nominal interest rate simultaneously.

We find that the behavior of the economy is quite similar under the monetary aggregate targeting, nominal interest rate targeting, and inflation rate targeting. When the real interest rate is taken as a monetary policy instrument, the larger consumption volatility in the short run accompanied by a smaller volatility in the long run causes significant welfare differences with respect to the other three targeting procedures. Therefore, not only the volatility of consumption but also its frequency is crucial to grasp the welfare implications of the alternative monetary instruments under consideration.

Let us finish our paper with a more precise comparison of our results with those obtained in the related literature. Comparing the two targeting instruments originally considered by Poole (1970), we find that the nominal interest rate targeting delivers higher welfare than the monetary aggregate targeting for technology and government spending shocks, and the monetary aggregate targeting is welfare improving when only money demand shocks affect the economy. Our results thus coincide with those of Carlstrom and Fuerst (1995) and Collard et al. (1998). ${ }^{9}$ However, our results contrast with those obtained by Canzoneri and Dellas (1998) where no procedure clearly dominated the other in terms of welfare. ${ }^{10}$ At the value $\theta=4$ for the relative risk aversion parameter our model predicts that, by using the nominal interest rate targeting, welfare can be improved by $5 \%$ with respect to the monetary aggregate targeting. Recall that Canzoneri and Dellas (1998) do not include a possibility of capital accumulation, while Collard et al. (1998) do allow for it. The presence of capital in the model enables the substitution between the capital accumulation and consumption, which is a new channel for the adjustment to shocks.

Collard and Dellas (2006) find that the inflation targeting leads to the highest welfare, but the differences from the nominal interest rate and monetary aggregate targeting are not significant. Inflation targeting in our model also leads to the highest welfare, but only when the relative risk aversion is low, i.e., when $\theta \leq 1$. For the relative risk aversion close to unity, switching from the inflation rate targeting to the monetary aggregate targeting or to the nominal interest rate targeting would mean a welfare loss of less than $0.01 \%$ of the consumption stream. For $\theta>1$, which is a

\footnotetext{
9 Carlstrom and Fuerst (1995) do not consider money demand shocks.

10 These authors considered a value of the risk aversion parameter between 1 and 4 .
} 
parametrization generally accepted in the literature, the fixed real interest rate is the targeting procedure that leads to the highest welfare. Our model predicts that for $\theta=2$ $(\theta=4)$ a switch from the inflation targeting towards the real interest rate targeting results in $9 \%$ (35\%) increase in the stream of consumption.

\section{Appendix}

\section{Transformed Equilibrium Equations}

Using the variables defined in (24) and (25), Eqs. 15, 5, 3, 11, 16, 18, 19, 21, 20, 22 and 9 become

$$
\begin{aligned}
\hat{c}_{t}+\gamma_{t+1}-(1-\delta)+\hat{g}_{t} & =\hat{y}_{t} \\
\hat{y}_{t} & =A_{t}\left(\psi \hat{g}_{t}\right)^{1-\alpha} \\
\hat{c}_{t} & =\hat{m}_{t}+s_{t}\left(1-\tau_{t}\right)\left(\hat{y}_{t}-\delta\right) \\
\hat{g}_{t} & =\tau_{t}\left(\hat{y}_{t}-\delta\right)+\left(\mu_{t+1}-1\right) \hat{m}_{t}+\frac{f_{t+1} \gamma_{t+1} \hat{b}_{t+1}}{1+i_{t+1}}-\hat{b}_{t}, \\
\mu_{t+1} & =\frac{\hat{m}_{t+1}}{\hat{m}_{t}} \gamma_{t+1} f_{t+1} \\
\hat{c}_{t}^{-\theta} & =\hat{\lambda}_{t}+\hat{\eta}_{t}, \\
\hat{\lambda}_{t} & =\beta E_{t}\left(\frac{\left.\hat{\lambda}_{t+1}+\hat{\eta}_{t+1} \gamma_{t+1}^{-\theta}\right)}{\hat{\lambda}_{t}}=\beta E_{t}\left\{\hat{\lambda}_{t+1} \gamma_{t+1}^{-\theta}\left\{1+\left(1-\tau_{t+1}\right)\left[\alpha \hat{y}_{t+1}-\delta\right]\right\}\right.\right. \\
\frac{\hat{\lambda}_{t}}{1+i_{t+1}} & =\beta E_{t}\left(\frac{\hat{\lambda}_{t+1}}{f_{t+1}} \gamma_{t+1}^{-\theta}\right) \\
\frac{\hat{\lambda}_{t}}{1+r_{t+1}} & =\beta E_{t}\left(\hat{\lambda}_{t+1} \gamma_{t+1}^{-\theta}\right)
\end{aligned}
$$

and

$$
\hat{g}_{t}=\left(A_{t} G_{t}\right)^{\frac{1}{\alpha}} \psi^{\frac{1-\alpha}{\alpha}}
$$

Setting the level of the technology $\ln A_{t}=\overline{\ln A}$, the efficiency of the payment system $\ln s_{t}=\overline{\ln s}$, and government spending to GDP ratio $\ln G_{t}=\overline{\ln G}$ constant for all periods, we get the equilibrium equations that characterize the non-stochastic (or deterministic) steady state.

Acknowledgements This paper has benefited from suggestions and comments from, an anonymous referee, Cruz Angel Echevarria, Luisa Fuster, Tim Kehoe, Hugo Rodriguez, and participants in the FEDEA 
seminar, the Meeting of the Society of Economic Dynamics, Symposium of Economic Analysis, and the Workshop on Dynamic Macroeconomics at the Universidade de Vigo. Financial support from the European Commission's Phare ACE Program, the Spanish Ministry of Science and Innovation through grants ECO2009-09847 and SEJ2007-60671, and the Generalitat of Catalonia through grant SGR2009-00350 is gratefully acknowledged.

\section{References}

Barro, J. R. (1990). Government spending in a simple model of endogenous growth. Journal of Political Economy, 98, S103-S125.

Bhattacharya, J., \& Singh, R. (2008). Optimal choice of monetary policy instruments in an economy with real and liquidity shocks. Journal of Economic Dynamics and Control, 32, 1273-1311.

Blackburn, K., \& Hung, V. T. Y. (1996). Equilibrium growth in a monetary economy. Seoul Journal of Economics, 9, 145-161.

Canzoneri, M. B., \& Dellas, H. (1998). Real interest rates and Central Bank operating procedures. Journal of Monetary Economics, 42, 471-494.

Carlstrom, C. T., \& Fuerst, T. S. (1995). Interest rate rules vs. money growth rules. A welfare comparison in a cash-in-advance economy. Journal of Monetary Economics, 36, 247-267.

Collard, F., \& Dellas, H. (2005). Poole in New Keynesian Model. European Economic Review, 49, 887-907.

Collard, F., \& Dellas, H. (2006). The case for inflation stability. Journal of Monetary Economics, 53, 1801-1814.

Collard, F., Dellas, H., \& Ertz, G. (1998). Poole revisited. IRES, Université Catolique de Louvain, Discussion Paper 9823.

Cooley, T. F. (1997). Calibrated models. Oxford Economic Policy, 13, 55-69.

Fishlow, A., \& Friedman, J. (1994). Tax evasion, inflation and stabilization. Journal of Development Economics, 43, 105-123.

Hodrick, R. J., Kocherlakota, N., \& Lucas, D. (1991). The variability of velocity in cash-in-advance models. Journal of Political Economy, 99, 258-384.

Hromcová, J. (2007). On income velocity of money, precautionary money demand and growth. Journal of Economics, 90, 143-166.

Kim, J., \& Henderson, D. W. (2005). Inflation targeting and nominal-income-growth targeting: When and why are they suboptimal? Journal of Monetary Economics, 52, 1463-1495.

Lucas, R. E., Jr. (2003). Macroeconomic priorities. American Economic Review, 93, 1-14.

Mankiw, G. N. (1987). Government purchases and real interest rates. Journal of Political Economy, 95, 407-419.

Palivos, T., \& Yip, C. K. (1995). Government expenditure financing in an endogenous growth model: A comparison. Journal of Money, Credit and Banking, 27, 1159-1178.

Pérez Sánchez, R. M. (2004). Characterizing the optimal composition of Government expenditures, Economic Working Papers at Centro de Estudios Andaluces E2004/81.

Poole, W. (1970). Optimal choice of monetary policy instruments in a simple stochastic macro model. Quarterly Journal of Economics, 84, 197-216.

Roubini, N., \& Sala-i-Martin, X. (1992). Financial repression and economic growth. Journal of Development Economics, 39, 5-30.

Roubini, N., \& Sala-i-Martin, X. (1995). A growth model of inflation, tax evasion, and financial repression. Journal of Monetary Economics, 35, 275-301.

Svensson, L. E. O. (1985). Money and asset prices in a cash-in-advance economy. Journal of Political Economy, 93, 919-944.

Uhlig, H. (1999). A toolkit for analyzing nonlinear dynamic stochastic models easily. Computational methods for the study of dynamic economies (pp. 30-61). Oxford and New York: Oxford University Press.

Woodford, M. (1991). Currency competition and the transition to monetary union: Does competition between currencies lead to price level and exchange rate stability? In A. Giovannini \& C. Mayer (Eds.), Integration European financial. Cambridge: Cambridge University Press. 